\title{
Lesser Mouse-Eared Bat Myotis blythii (Tomes, 1857)
}

Manuel Ruedi

\section{Contents}

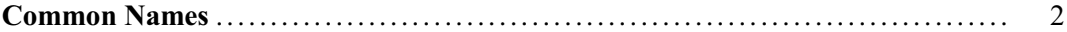

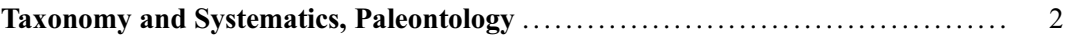

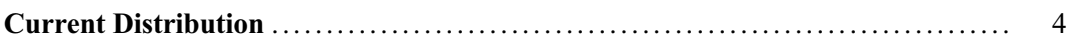

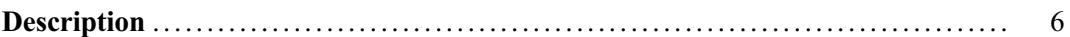

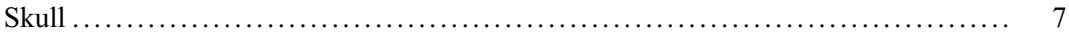

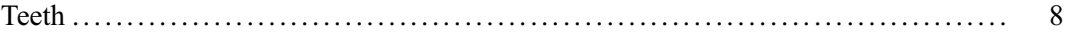

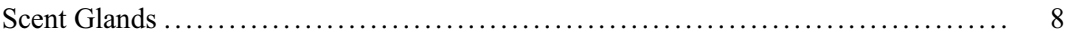

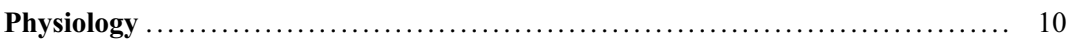

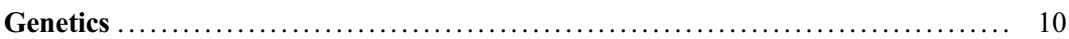

Chromosomes ................................................... 10

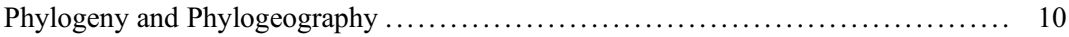

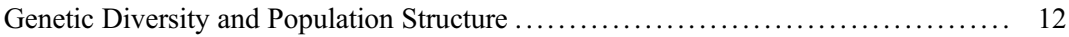

Hybridization with Related Species ..................................... 12

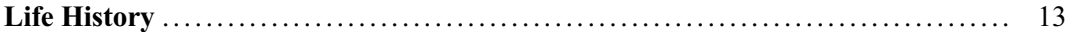

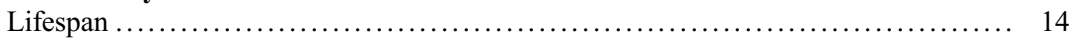

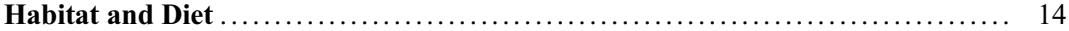

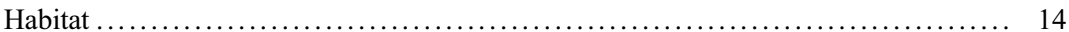

Spatial Movements .................................................... 15

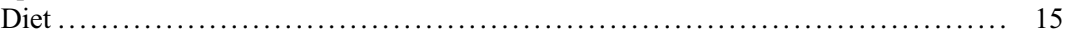

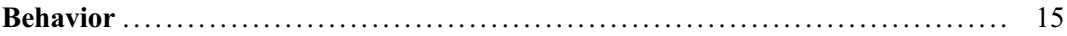

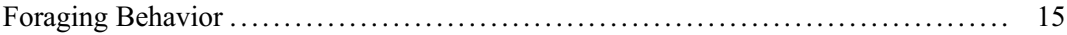

Resource Competition .................................................. 16

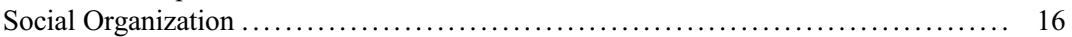

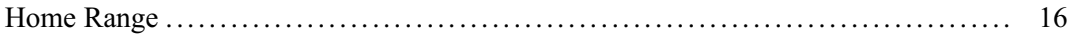

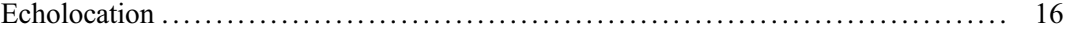

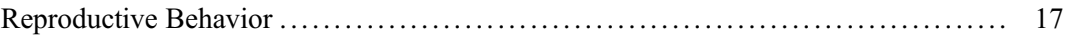

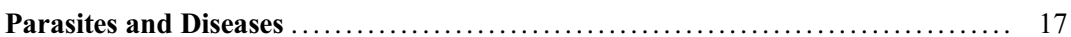

M. Ruedi $(\bowtie)$

Natural History Museum of Geneva, Geneva, Switzerland

e-mail: manuel.ruedi@ville-ge.ch

K. Hackländer, F. E. Zachos (eds.), Handbook of the Mammals of Europe, Handbook of the Mammals of Europe, https://doi.org/10.1007/978-3-319-65038-8_60-1 


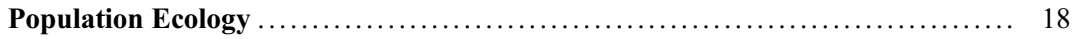

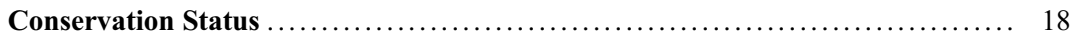

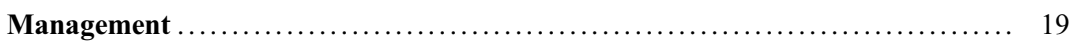

Future Challenges for Research and Management ....................... 19

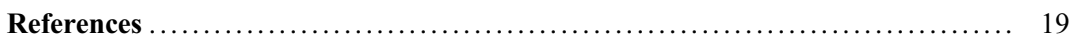

\section{Common Names}

Lesser mouse-eared bat; Kleines Mausohr; Petit murin; Murciélago ratonero mediano; Vespertilio minore; Ночница трёхцветная

\section{Taxonomy and Systematics, Paleontology}

The taxonomy and systematics of large Myotis in Europe and Asia has been always contentious and is still probably not fully resolved yet. The very first member of this group was known over a century as Vespertilio murinus Linnaeus, 1758, until Miller (1897), arguing on some dental inconsistencies appearing in the original description, reassigned it to the species Myotis myotis (Borkhausen, 1797). A second, smaller species in this group was described from southern Italy by Monticelli (1885), who named it Vespertilio [= Myotis] oxygnathus. This name prevailed in the literature until Ellerman and Morrison-Scott (1951), Topál (1971), and Strelkov (1972) made global revisions of the large Myotis of the Old World. These zoologists realized that the taxon Vespertilio [= Myotis] blythii, described earlier by Tomes (1857) from the Indian subcontinent, was morphologically very similar to the European oxygnathus and thus proposed to include the latter as a junior synonym of $M$. blythii, the lesser mouse-eared bat. These global revisions further showed that the intervening populations from Asia Minor were also similar to $M$. blythii, albeit slightly larger, almost reaching in size as that of M. myotis, and classified them as a distinct subspecies, M. blythii omari Thomas (1905). A last, isolated population from southern Siberia and northern China was assigned to a fourth subspecies, M. blythii ancilla Thomas (1910).

Most subsequent authors followed this systematic arrangement with little variation (e.g., Koopman 1994; Corbet 1978; Topál and Ruedi 2001), which was further supported by many univariate and multivariate analyses based on craniodental characters (e.g., Benda and Horácek 1995; Felten et al. 1977). Geometric morphometric analyses conducted with extensive Eurasiatic skull material also showed that all these forms associated to $M$. blythii were more similar to each other than to sympatric M. myotis or to $M$. punicus from North Africa, supporting again this prevailing taxonomic view (Evin et al. 2008). According to these studies, M. blythii s.l. was considered as a widespread, polytypic species with four distinct subspecies distributed as follows: the nominal $M$. b. blythii occupies the southern belt of the Himalayas from Nepal west to Afghanistan (Benda and Gaisler 2015) and parts of Central Asia (Benda et al. 2011). In an area coinciding with the Kopet Dagh Mountains (i.e., close to the oriental border of Iran), animals appear distinctly larger and represent $M . \quad b$. omari, a subspecies commonly found elsewhere in the Middle East, west to central Anatolia (Harrison and Lewis 1961; Benda et al. 2006; Benda and Horácek 1998), in the Caucasus (Benda et al. 2011), in Cyprus (Benda et al. 2007, 2018), and possibly in Crete (Georgiakakis et al. 2012). In western Anatolia, lesser mouse-eared bats show a clinal decrease of size toward the west (Felten et al. 1977; Benda and Horácek 1998; Furman et al. 2014), which is reflected by a transition zone between the larger $M . b$. omari and the smaller M. b. oxygnathus, found in Europe. The last subspecies is confined to Far Eastern Asia (Altai Mountains and northern China) and is assigned 
to M. b. ancilla by most authors (Topál 1971; Kruskop et al. 2012; Benda et al. 2011).

This view prevailed until the first DNA-based comparisons between western European and Asian samples were published (Ruedi and Mayer 2001; Castella et al. 2000), which showed that mitochondrial lineages of $M$. myotis and $M$. b. oxygnathus were much more closely related to each other (sometimes even identical) than the latter were to M. b. blythii from Kyrgyzstan. Given this puzzling pattern and in an attempt to recover monophyletic groups within this species complex, Simmons (2005) proposed to split again the Indian and European taxa as two independent species (i.e., $M$. blythii and M. oxygnathus) but failed to reconsider the intervening (and at that time genetically unsampled) populations representing $M$. b. omari. This triggered new nomenclatural confusion, as both names (M. blythii and M. oxygnathus) were used by various authors to designate the same European taxon (e.g., Bogdanowicz et al. 2009; Furman et al. 2013; Dietz et al. 2007; Dietz and Kiefer 2015; Russo et al. 2007).

To complicate the story further, new molecular evidence based on both mitochondrial and nuclear markers showed that European lesser mouse-eared bat carry a mitogenome (mtDNA) that was partly inherited through introgression from its sister species, M. myotis, hence compromising species phylogenies based solely on mtDNA markers (Berthier et al. 2006; Furman et al. 2014). Furman and colleagues $(2013,2014)$ further evidenced that populations of $M$. blythii s.l. sampled from across the entire Western Palaearctic region did not mark any substantial genetic break coinciding with the transition zone between $M$. b. oxygnathus and $M . b$. omari in Turkey. This again suggested the existence of a continuum of interbreeding populations across vast areas of Europe and the Middle East, which also contradicted the systematics arrangement proposed by Simmons (2005).

Unfortunately, no comparable molecular transect has been conducted so far in other parts of the Asian distribution range of $M$. blythii. Thus, no definitive conclusion about the global species status of those populations can be reached. However, based on the rather modest genetic distances evidenced between samples separated by thousands of kilometers (see Fig. 1), we adopt here the traditional view of considering all these forms within a single, polytypic species $M$. blythii. This conservative view is, for instance, reflected in phylogenetic reconstructions based on multiple genes (Ruedi et al. 2013; Morales et al. 2019) or on simpler reconstructions based on barcode (COI) sequences issued from all subspecies of lesser mouse-eared bat (Fig. 1).

According to fossil-calibrated molecular phylogenies, Ruedi et al. (2013) estimated that ancestral M. blythii diverged from other large Eurasian Myotis during the Early-Middle Miocene, some 13 MYA. Within that group, M. blythii s.l. started diverging from its common ancestor with $M$. punicus in the Late Miocene, about 6 MYA. Modern subspecies within M. blythii s.l. further radiated during the Pliocene (about 3 MYA), but because $M$. myotis was nested within this recent radiation, exact dates based on molecular divergences in this this group could not be inferred.

The fossil record largely corroborates these divergence dates, as the most ancient remains assigned to M. blythii s.l. discovered in the Hungarian locality of Osztramos are dated to the Middle Pliocene (Biozone MN15, Topál 1983). Further paleontological remains and ancient lineages of M. blythii were found in scattered places of eastern and southern Europe throughout the Pleistocene (see, e.g., Salari 2010; Salari et al. 2013; Topál and Ruedi 2001). The species, however, progressively disappeared from most of Europe by the Late Pleistocene, suggesting that all current populations of lesser mouse-eared bat vanished at the onset of the Last Glacial epoch. Exceptions might include the extreme southern tip of the Apennine Peninsula, which apparently supported cave roosts occupied by this species even during the Last Glacial Maximum (Salari et al. 2019). Globally, however, modern populations of $M . \quad b$. oxygnathus must have recolonized Europe postglacially, probably from Anatolia (Coraman et al. 2013), as suggested by the increasingly common fossils of that species found across this region in Holocene deposits (e.g., Topál and Ruedi 2001; Kordos 1981; Popov and Ivanova 1995). Interestingly whereas fossilized M. myotis was reported without 


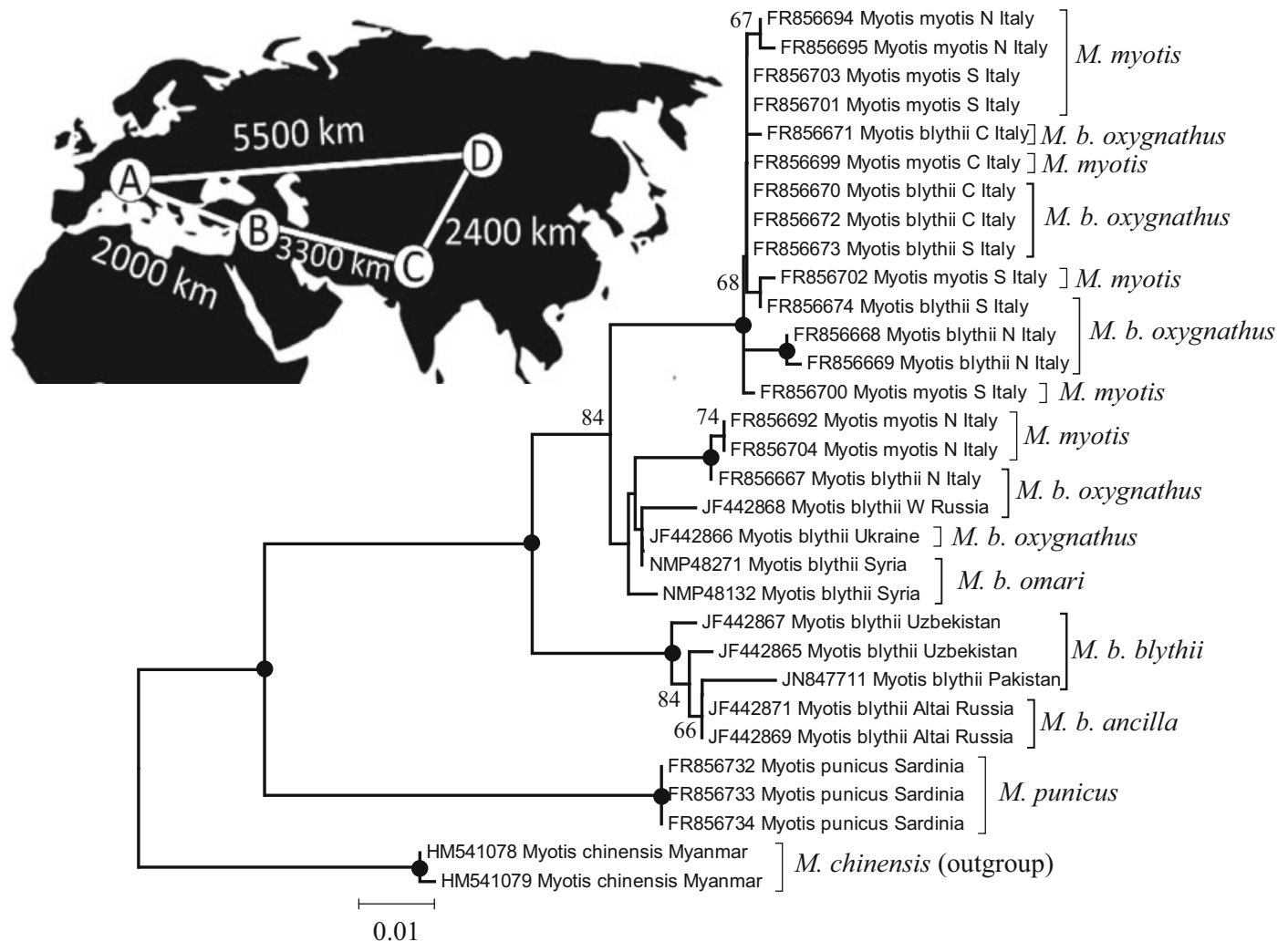

Fig. 1 Neighbor-joining tree illustrating haplotype relationships of large Myotis species based on an alignment of their mitochondrial barcode gene (COI) recovered from public repositories. The GenBank number of each sequence is followed by its associated taxon name and country of origin. This reconstruction is based on a matrix of pairwise genetic distances (Kimura 2-parameter) and with $M$. chinensis used as an outgroup. Values at the nodes indicate the bootstrap support for 1000

interruption throughout Pleistocene deposits in the Iberian Peninsula, no firmly identified fossils of $M$. blythii dating from that epoch were recorded (Sevilla 1988, 1989; Galán et al. 2019) implying that M. myotis persisted during the Pleistocene in Western Europe, but not M. blythii (Galán et al. 2019).

\section{Current Distribution}

Previous surveys of morphological variation (Benda and Horácek 1995; Topál 1971; Evin et al. 2008; Spitzenberger 1996) show that most of pseudoreplicates (filled symbols represent $>95 \%$ support). The inset is a sketch of approximate geographic distances separating the samples, with letters indicating the type localities of (A) M. b. oxygnathus (Italy), (B) M. b. omari (Iran), (C) M. b. blythii (N India), and (D) M. b. ancilla (N China). Notice that sequences of $M$. $b$. oxygnathus are paraphyletic regarding those of $M$. myotis, which reflects the massive introgression of mitochondrial genes which occurred in Europe between these two species

the distribution range of $M$. blythii in Europe refers to the subspecies M. b. oxygnathus. Exceptions are the islands of Cyprus (Benda et al. 2007), and possibly Lesbos (Hanak et al. 2001; Iliopoulou-Georgudaki 1984) and Crete (Georgiakakis et al. 2012), which are inhabited by the slightly larger subspecies $M$. $b$. omari. The lesser mouse-eared bat is notably absent from the Mediterranean islands of Corsica, Sardinia, or Malta, which are inhabited by another large mouse-eared bat (M. punicus). In continental Europe, M. b. oxygnathus is a typical thermophilous species found from the Iberian Peninsula to the Balkans and Turkey and along the northern 
coasts of the Black Sea, east to southern Crimea (Fig. 2). Lesser mouse-eared bats hardly occur beyond the latitude of $49^{\circ}$ north. Indeed, $M . b$. oxygnathus is, for instance, only marginally present or very rare north of the Alps. In this region, the northernmost nursery colonies are found in the French department of Jura $\left(46^{\circ} 44^{\prime} \mathrm{N}\right)$, although few isolated individuals have been mentioned further north (Caël 2018). Likewise, in Central Europe, the northern margin of its breeding range reaches the latitude of $49^{\circ}$ north in the mountainous regions of Slovakia (Uhrin et al. 2008). The marginal record of a single male caught further north in a wintering site in the Tatra Mountains, in extreme southern Poland (Piksa 2006), also probably represents a vagrant individual and is not a sign of permanent population in this country (Uhrin et al. 2008). Most of the breeding grounds of the species in Central Europe are limited by the Sudetes and Carpathian mountain ranges (Bachanek 2008). Further east, the species is commonly found throughout the Balkans, in the Transcarpathian region of Ukraine, up to the southern parts of Crimea (Uhrin et al. 2008).

In the Caucasus (Sevilla 2016) and in parts of Anatolia, this European form is replaced by the larger subspecies $M$. b. omari, which extends its distribution east across Transcaucasia to W Turkmenistan (Benda et al. 2011). Elsewhere in the Near East, $M$. b. omari is also present in the Levant, south to northern Israel and Jordan (Mendelssohn and Yom-Tov 1999; Benda et al. 2010), and east across Syria, Iraq, and Iran (Benda et al. 2006, 2012). In the oriental parts of the Kopet Dagh Mountains in Iran, this subspecies is replaced by the nominal $M . b$. blythii, which is widespread from Afghanistan to $\mathrm{N}$ India and Nepal along the foothills of the Himalayas (Benda and Gaisler 2015). In Central Asia, this nominal subspecies is found up to Kyrgyzstan and SE Kazakhstan and to W Turkestan (Benda and Gaisler 2015). Finally, sparse records in the Altai region of Siberia and northern China are attributable to the fourth subspecies, M. b. ancilla (Benda et al. 2011; Kruskop et al. 2012).

The lesser mouse-eared bat in Western Europe is considered as rather rare, while it appears to be more common in the Eastern countries (Juste and
Paunović 2016). However, exact figures of population sizes and trends are very difficult to assess because $M$. blythii often shares roosts with its sibling species M. myotis. Visual counts or even rough estimates of either species are thus generally impossible to realize (Uhrin et al. 2008; Spitzenberger 2001), and local populations are usually reported as a combined figure for the two species (e.g., Nogeras and Garrido 2007; Bihari 1998). In the few countries where population counts are available, for instance in Portugal, this species is considered very rare with about 2000 individuals estimated, mainly located in the Algarve and Trás-os-Montes regions (Rainho et al. 2013; Cabral et al. 2005). Likewise, Spain and France hold each less than 20,000 individuals, with populations concentrating in the southern parts of those countries (Juste and Paunović 2016; Caël 2018). In Switzerland, the species is considered as critically endangered due to sharp declines in the last decades, with probably less than 100 mature individuals surviving in 12 known breeding colonies (Bohnenstengel et al. 2014). In Austria, the situation is also critical, with sharp decreases in the number of known maternity colonies installed in the eastern regions (Spitzenberger 2001).

No precise estimates have been done in Slovakia, but this species seems to be more common and has been found in over a quarter of the surface of the country, with several colonies numbering over hundred females found in the southern, karstic parts of the country (Uhrin et al. 2008). In the Balkans (e.g., Greece, Romania, Bulgaria, Hungary, etc.), and on several islands like Crete, the lesser mouse-eared bat is considered both widespread and common (e.g., Benda et al. 2009; Hanak et al. 2001), with some nursery colonies numbering several thousand individuals (Dietz and Kiefer 2015). On Cyprus, however, this is a rare bat only found in a couple of localities (Benda et al. 2007, 2018). Outside of Europe, this bat species is often reported as one of the most widespread and abundant cave bats (e.g., Benda et al. 2006, 2012; Așan et al. 2010; Sevilla 2016). 
Fig. 2 Distribution map of M. blythii in Europe (in red). Notice that except for the Caucasus, Cyprus, few Aegean Islands (e.g., Lesbos), and possibly Crete which are inhabited by $M . b$. omari, this range corresponds to the current distribution of $M . b$. oxygnathus. Other extralimital subspecies of $M$. blythii are not depicted in this map. This distribution is essentially based on the IUCN Red List of Threatened Species (Juste and Paunović 2016)

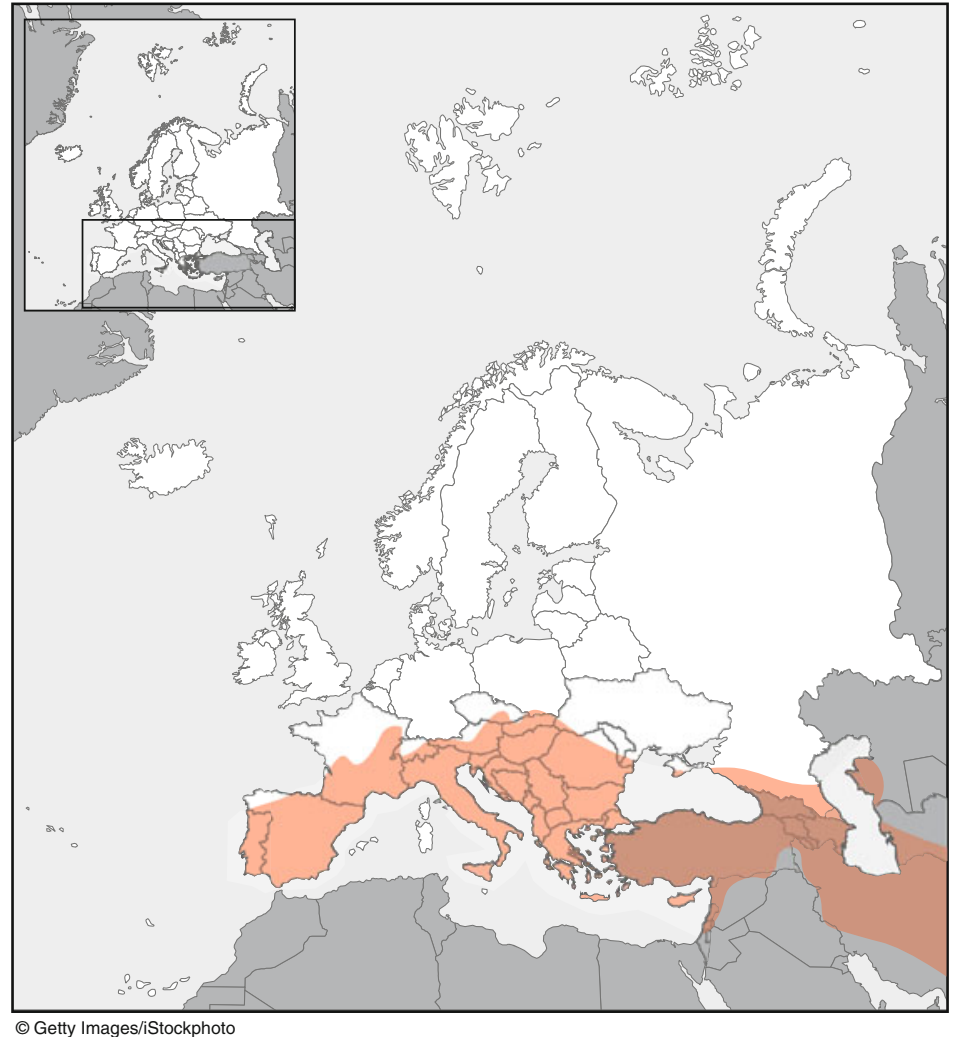

\section{Description}

The lesser mouse-eared bat is a relatively large bat weighting 15-30 $\mathrm{g}$ and with a wing span of 35$40 \mathrm{~cm}$. Its broad and long wings are typical characteristics of gleaner species. As in other vespertilionids, this species has no special structures on the nose, and its tail is completely contained in the uropatagium. The general color of the dorsal pelage is grayish-brown with dark hair basis. Ventral parts are grayish-white with a rather well-marked delineation between the dorsal and ventral fur (Fig. 3). On the sides of the neck or near the shoulders, the whitish fur is sometimes tinged with yellow. Young and immature animals born during the summer are distinctively grayer dorsally and more whitish ventrally than adult animals. They can also be recognized by a darker chin spot, which becomes progressively flesh color after 1 or 2 years (Arlettaz 1995). Animals living in the southern, more desertic parts of its range are lighter brown, almost fawn dorsally, and have also lighter coloration of the naked parts (ears, face, and wing membranes). In Europe, a small white spot between the ears is present in a variable proportion of individuals (Arlettaz et al. 1991). When present, this is a good discriminant character as M. myotis lacks such a white spot. The muzzle of lesser mouse-eared bats is also more slender and narrower than that of the latter species (Fig. 3). Wing membranes and uropatagium are light brown and largely naked, except for areas immediately adjacent to the body. Hind feet have strong claws, and their size (mean $12.0 \mathrm{~mm}$ ) is less than half the tibia length (mean $25.7 \mathrm{~mm}$ ) (Topál and Ruedi 2001).

The unnotched ears of lesser mouse-eared bats are relatively long (20-24.3 mm) and narrow (13$16 \mathrm{~mm}$ ). Both dimensions of the ear are larger in M. myotis ( $>24 \mathrm{~mm}$ long and $>16 \mathrm{~mm}$ wide), but these distinctive metric characters are only valid for European bats, as both species increase clinically clinally in size in the Levant and Anatolia regions (Spitzenberger 1996) or on some islands 


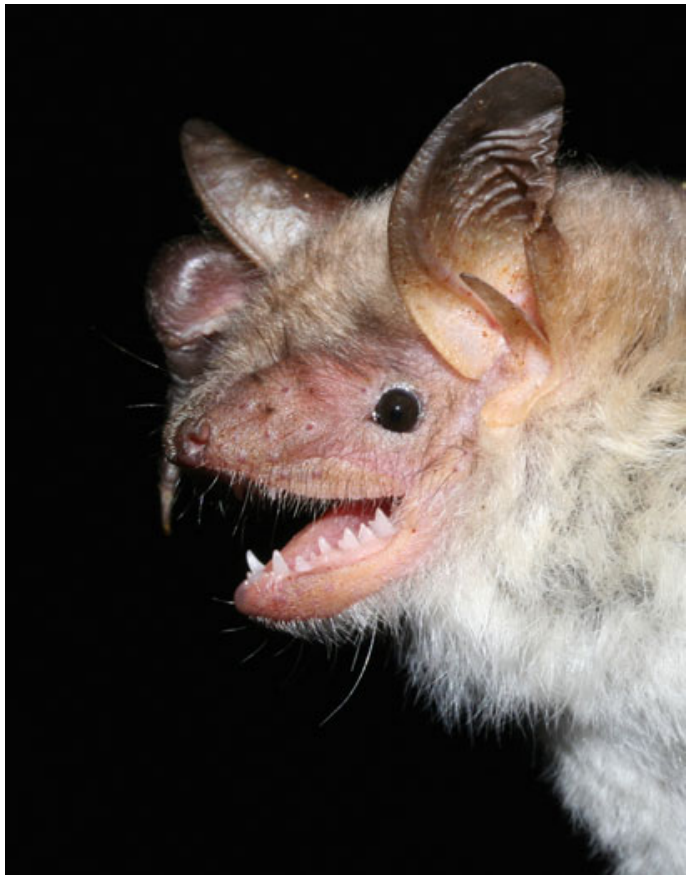

Fig. 3 Portrait of an adult male lesser mouse-eared bat (Myotis blythii oxygnathus) from the Swiss Jura Mountains. (Photo courtesy of Cyril Schönbächler, CCOGeneva)

of the Eastern Mediterranean (Hanak et al. 2001). The tragus is only slightly bent forward, the external border being more convex that the internal one, which is almost straight (Fig. 3). The tragus height reaches about half the length of the pinna. As seen in Fig. 3, lesser mouse-eared bats do not have the distinctive darker spot at the very tip of the tragus which is usually present in most greater mouse-eared bats (Dietz and Kiefer 2015). This character and the white spot between the ears have not been thoroughly evaluated outside of Europe but seem of limited value in the few South Asian specimens examined (pers. obs.).

The mean forearm length of $M$. b. oxygnathus, like many other measurements (see Table 1), is also smaller than in M. myotis but with broadly overlapping extreme values (Benda and Horácek 1995). Females have slightly larger forearms than males (about $2 \mathrm{~mm}$ difference). To help differentiate those two species, Arlettaz et al. (1997b) proposed the following discriminant function based on a combination of forearm length (FAL) and ear length (EAL):

$$
\begin{aligned}
Z= & 0.1084 * \mathrm{FAL}+1.4166 * \mathrm{EAL} \\
& -40.5907
\end{aligned}
$$

If the $Z$ value is below -0.5 , the measured bat is likely $M$. blythii and if above 0.5 likely $M$. myotis; animals showing intermediate values cannot be identified. The ear length measurement is, however, quite difficult to take accurately on live animals, and other qualitative characters should complement results from this classification function.

For any of those phenetic characters and including for this classification function, few bats may present intermediate values and likely represent atypical or hybrid individuals (see sections below). These bats are thus impossible to assign to one of the parental species based on morphology, unless the skull can be examined (Bachanek and Postawa 2010; Galán et al. 2019). Nuclear, biparentally inherited markers would be the only alternative to identify such intermediate individuals and to assess their hybrid status (Berthier et al. 2006).

\section{Skull}

The skull and dentition of lesser mouse-eared bat are smaller and weaker than in greater mouseeared bats (see Table 2); most craniodental characters are discriminant between those two species living in sympatry (Ghazali 2009; Benda and Horácek 1995; Galán et al. 2019). In particular, the length of upper toothrow (CM3) is less than $9.3 \mathrm{~mm}$ (usually $<9.0 \mathrm{~mm}$ ) in $M$. b. oxygnathus, while it exceeds $9.4 \mathrm{~mm}$ in M. myotis. This character can be measured readily on live animals, but precautions must be taken to avoid injuring the gum or the teeth and is best taken with a plastic caliper. The total length of the skull (GLS $<22.6 \mathrm{~mm}$ ) or the length of the mandible (LMd $<17.2 \mathrm{~mm}$ ) also provide good characters to identify lesser mouse-eared bats. Contrary to some 
Table 1 External measurements (expressed in $\mathrm{mm}$ ) of adult $M$. b. oxygnathus from both sexes captured in a population from Valais, Switzerland. $n$ sample size, mean mean value, min smallest value, max largest value, $S D$ standard deviation; $W G T$ weight (in grams), FAL forearm length, $3 D G T$ third digit length, $5 D G T$ fifth digit length, EAL ear length, TAIL tail length, TIBIA tibia length, and WSPAN wing span. (Data from Arlettaz et al. (1991))

\begin{tabular}{|c|c|c|c|c|c|c|c|c|c|c|}
\hline \multicolumn{11}{|c|}{ M. b. oxygnathus } \\
\hline & \multicolumn{5}{|c|}{ Males } & \multicolumn{5}{|c|}{ Females } \\
\hline & $n$ & Mean & Min & Max & SD & $n$ & Mean & Min & Max & SD \\
\hline WGT & 40 & 21.8 & 18.0 & 28.0 & 0.6 & 44 & 21.8 & 17.5 & 29.5 & 3.2 \\
\hline FAL & 88 & 56.1 & 50.5 & 60.1 & 1.8 & 79 & 58.0 & 54.2 & 62.0 & 1.5 \\
\hline 3 DGT & 40 & 94.0 & 85.0 & 101.2 & 3.4 & 44 & 96.9 & 91.5 & 103.0 & 2.7 \\
\hline 5 DGT & 40 & 73.4 & 68.0 & 79.5 & 2.4 & 44 & 74.7 & 70.4 & 81.4 & 2.3 \\
\hline EAL & 78 & 22.8 & 21.0 & 24.0 & 0.6 & 68 & 23.0 & 20.8 & 24.3 & 0.6 \\
\hline TAIL & 12 & 56.3 & 52 & 65 & 4.0 & 6 & 56.8 & 51 & 60 & 3.1 \\
\hline TIBIA & 12 & 25.7 & 24.5 & 26.5 & 0.6 & 6 & 25.7 & 24.5 & 26.8 & 0.9 \\
\hline WSPAN & 12 & 379.4 & 365 & 389 & 7.8 & 6 & 383.3 & 368 & 408 & 13.9 \\
\hline
\end{tabular}

external measurements of the wing, skull or dental measurements do not show sexual dimorphism in size (Galán et al. 2019; Bachanek and Postawa 2010).

Based on comparative geometric morphometric analyses of skulls, Evin et al. (2008) further showed that all subspecies of $M$. blythii are characterized by a relatively broader and higher cranium, a longer lambda and occipital foramen, a less rounded braincase, and a shorter rostrum when compared to M. myotis or to M. punicus. Furthermore, these multivariate analyses showed that Anatolian M. b. omari and North African $M$. punicus differ markedly in skull shape, although both share very similar overall sizes. Conversely, all analyzed subspecies of $M$. blythii share a similar skull shape, while they do differ significantly in terms of size (Evin et al. 2008).

\section{Teeth}

Like most species of Myotis, M. blythii possess 38 teeth, with two upper and three lower incisors, one upper and lower canine, three upper and lower premolars, and three upper and lower molars. Their permanent dentition is thus 2.1.3.3/ 3.1.3.3 = 38 teeth. The first two upper and lower premolars are much smaller in both height and crown area when compared to the third, a typical feature of the genus. All lower molars have a myotodont configuration (Menu and Sigé 1971).
In general, the smaller and less robust molars of $M$. blythii are useful qualitative dental characters to discriminate it from its sibling species $M$. myotis. But a more reliable tooth character is the unreduced talonid part of its third lower molar (m3), which is thus relatively wider when compared to the narrower third molar of M. myotis (Topál and Tusnadi 1963). Galán et al. (2019) and Ghazali (2009) give further details of teeth measurements that are useful to identify fragmentary material, but they also warn on the effect of age on such craniodental-based identification, as skulls of juvenile $M$. myotis may appear metrically closer to M. blythii than to their own species.

\section{Scent Glands}

Numerous glandular cells are present on the sides of the muzzle of lesser mouse-eared bats; they exude a sebaceous secretion that is particularly odoriferous in adult males. These secretions may dye with a yellowish-orange tinge the sides of the neck of their fur and are also used to mark hanging places where those bats roost individually. Males also probably rub these secretions against the females during the mating period (Horácek and Gaisler 1985-86). 


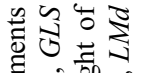

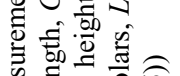

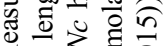
छ

《氙焉

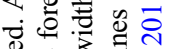

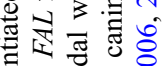

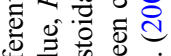

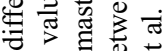

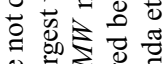

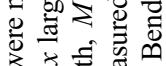

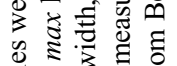
শิ भू 응

表

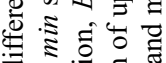

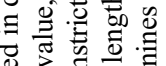
远

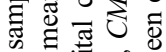
: इ 空苛苛

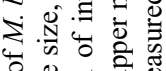

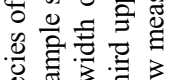

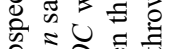
क्

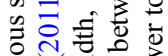

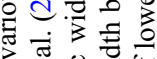

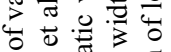

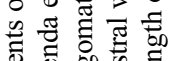

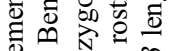
콘 要

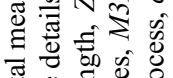
要递兽

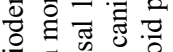
․ㅖ

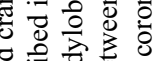

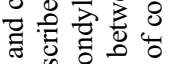
Эิ웡

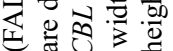

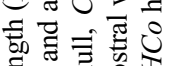
可 ह छับ论

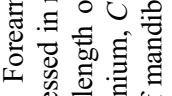

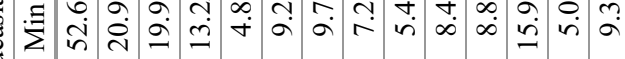

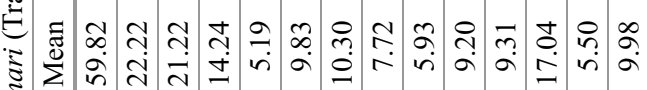

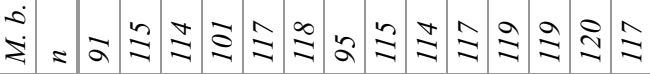

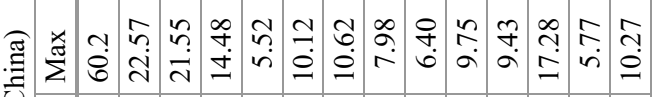

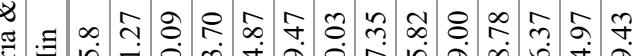
ฮี

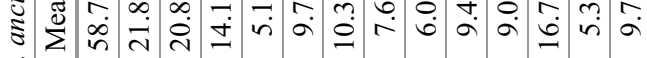

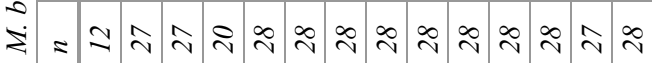
จิ 苛

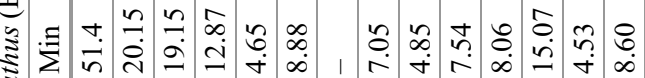

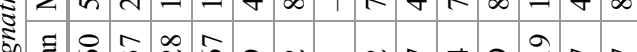

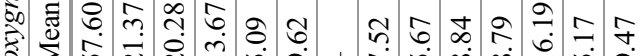

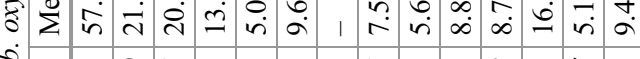

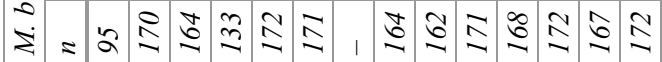

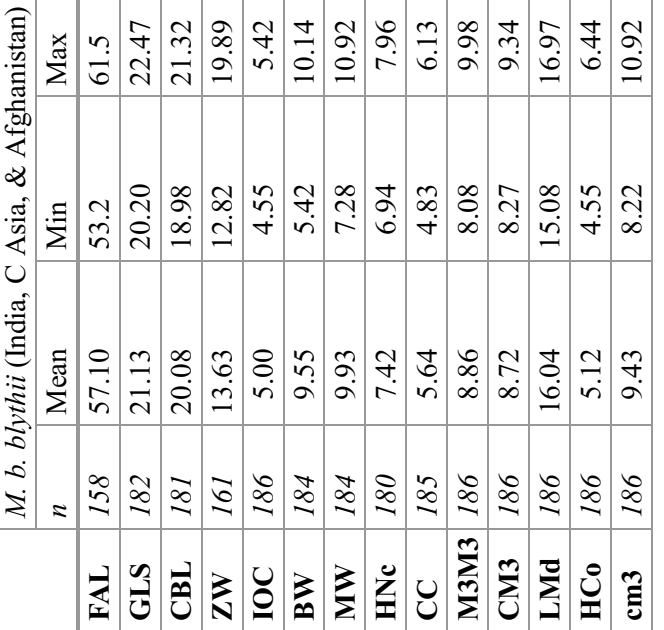




\section{Physiology}

Like most bats living in temperate regions, lesser mouse-eared bat are able to thermoregulate actively their body temperature (Altringham 2011). They are able to enter both into daily torpor in order to optimize their energetic demands (Johnson and Lacki 2014) or into deeper and much more prolonged torpors for hibernation (Ransome 1990). Outside the hibernating period, M. blythii is clearly a thermophilous species that seeks warm roosts in underground cavities or in human constructions, for instance to establish its nursery colonies. The availability of such thermically favorable summer roosts may be a limiting factor explaining why it is largely restricted to the Mediterranean or to the climatically warmest continental habitats. Alternative explanations involve the availability of particularly profitable prey during critical times of the year (Arlettaz et al. 2001a). In late autumn, lesser mouse-eared bat favors colder and humid roosts located in more northerly, more mountainous, or in underground habitats at higher altitude to enter into hibernation (Uhrin et al. 2008). Depending on the local climatic conditions, these bats will enter into hibernation in October and start emerging from winter roosts in March or April. During hibernation, these bats may roost alone or in small groups hidden in crevices or fissures of caves or mines or may form large wintering aggregate hanging to the walls of these cavities. Animals stay in tight contact and form wintering clusters that often comprise other troglophilous bats (Topál and Ruedi 2001).

\section{Genetics}

\section{Chromosomes}

The diploid number of chromosomes found in $M$. blythii is $2 \mathrm{n}=44$, with a fundamental number of chromosomal arms of FN $=54-56$ (Așan et al. 2011; Arslan and Zima 2014). The female sex chromosome $(\mathrm{X})$ is a large metacentric, while the $\mathrm{Y}$ chromosome is a small acrocentric. Standard Giemsa staining or higher resolution G- or C- banding methods used to differentiate chromosomes did not reveal any significant difference between the karyotypes of the two sibling species M. myotis and M. blythii (Așan et al. 2011; Karataş et al. 2004, 2008; Volleth and Heller 2012). As most other species of Myotis also share these general characteristics, karyotypes appear of little use for phylogenetic or taxonomic inferences in that genus (Zima 1982).

\section{Phylogeny and Phylogeography}

The genus Myotis comprises nearly 130 nominal species and is distributed worldwide (Burgin et al. 2018). In a comprehensive molecular analysis of most species, Ruedi et al. (2013) showed that the different lineages of $M$. blythii are part of a group called the "large Myotis" and form a strong clade together with M. myotis, M. punicus, $M$. nattereri s.l., and M. chinensis. This clade occupies a relatively basal phylogenetic position within other Eurasian species that diverged some 13 MYA from other sister taxa in the Old World. The sister species of M. blythii s.l. is M. punicus from which it diverged some 6 MYA. However, as mentioned in the previous sections, the group containing the different lineages of modern M. blythii s.l. also comprise those of M. myotis, rendering the species paraphyletic (Ruedi and Mayer 2001). This is, for instance, exemplified by the relationships of mitochondrial barcode sequences of European origin illustrated on Fig. 1 or on other reconstructions based on different mtDNA genes (e.g., Mayer and Helversen 2001; Bogdanowicz et al. 2009; Ibáñez et al. 2006; Furman et al. 2013). These paraphyletic relationships of European taxa reflect the multiple introgression events which occurred with the mitochondrial genome of those two species in that region (Berthier et al. 2006) and might therefore not reflect the phylogenetic relationships of the species themselves (Ballard and Whitlock 2004). For that purpose, phylogenetic reconstructions based on multiple independent nuclear markers would be necessary, as suggested by the ongoing studies conducted by Morales and coworkers (Morales et al. 2019). 
Table 3 Genetic diversity within mtDNA control region (HVII) haplotypes found in M. myotis (Mm) and M. blythii s.l. $(M b)$ sampled across the Western Palaearctic. These haplotypes have been grouped into the six major clades found in this region. Abbreviations: $n$ sample size; $H$ number of haplotypes; $H_{M m}$ haplotypes exclusive to $M$. myotis; $H_{M b}$ haplotypes exclusive to $M$. blythii s.l.; $H_{M m / M b}$ haplotypes shared by both species; $H$ ? haplotypes belonging to unidentified individuals; $H$ d haplotype diversity; $p$ nucleotide diversity. (Data from Furman et al. (2013))

\begin{tabular}{l|l|l|l|l|l|l|l|l}
\hline Clades & $n$ & $H$ & $H_{M m}$ & $H_{M b}$ & $H_{M m / M b}$ & $H ?$ & $H \mathrm{~d}$ & $p(\%)$ \\
\hline A & 599 & 39 & 31 & 4 & 3 & 1 & $0.52 \pm 0.03$ & $0.30 \pm 0.02$ \\
\hline B & 106 & 10 & 10 & 0 & 0 & - & $0.61 \pm 0.05$ & $0.94 \pm 0.13$ \\
\hline C/E & 69 & 11 & 6 & 3 & 2 & - & $0.78 \pm 0.03$ & $1.43 \pm 0.09$ \\
\hline D & 354 & 100 & 16 & 71 & 10 & 3 & $0.94 \pm 0.01$ & $1.38 \pm 0.06$ \\
\hline F & 55 & 16 & 7 & 8 & 1 & - & $0.87 \pm 0.03$ & $0.98 \pm 0.09$ \\
\hline Azokh & 34 & 13 & 0 & 13 & 0 & - & $0.90 \pm 0.03$ & $1.09 \pm 0.16$ \\
\hline
\end{tabular}

At the intraspecific level, several phylogeographic studies based on mtDNA markers have been conducted on M. blythii (e.g., Mayer and Helversen 2001; Bogdanowicz et al. 2009; Ibáñez et al. 2006; Furman et al. 2013; Galimberti et al. 2010). All show that some mitochondrial lineages sequenced in European lesser mouse-eared bat are minimally divergent (less than $5 \%$ ) or even absolutely identical to those of greater mouse-eared bats. Even the highly variable and rapidly evolving mtDNA control region (HVII) can be identical ( $0 \%$ divergence; Table 3$)$ between those two species sampled over extensive areas (Furman et al. 2013; Berthier et al. 2006). Within the Western Palaearctic region, Furman and colleagues determined that the mitochondrial lineages found in M. blythii s.l. could be subdivided into six major haplogroups (Table 3): three of them (Clade A, Clade B, and Clade C/E) are restricted to Europe west of the Bosporus, two (Clade F and Clade D) are distributed in the Balkans and Turkey, and one (Clade Azokh) is endemic to the Caucasus. All of them, except Clade B and Azokh, have been detected in both M. myotis and M. blythii (see Table 3).

Given this phylogeographic pattern of divergence and considering that most ancient populations of $M$. blythii probably disappeared from Europe during the Last Glacial Period while the forest-adapted M. myotis persisted at least in Southwestern Europe (see above chapter on palaeontology), Furman et al. (2014) proposed the following scenario to explain the intricate evolution of both species during the
Holocene: modern populations of M. blythii expanded into Eastern Europe during the Early Holocene from a glacial refuge in the Near East, possibly located in Anatolia (Coraman et al. 2013). During this movement of recolonization, the populations entering into the Balkans met and hybridized locally with the resident M. myotis, which triggered extensive mitochondrial introgression (Berthier et al. 2006). This introgressed population of $M$. blythii expanded further into the rest of Western Europe to occupy the current distribution of lesser mouse-eared bat (Fig. 2). At the same time, M. myotis also expanded its range beyond its former strictly European distribution but in the opposite direction and entered into the forested habitats of the Near East region. Approximately, in the Bosphorus region, these new invaders also hybridized locally with resident $M$. blythii and acquired their mitochondrial lineages. Hence, according to this scenario of bidirectional invasions by the two species, the Western European clades (Clades A, B, and C/E) would be originally found only in preglacial populations of M. myotis, while those from Anatolia and the Caucasus (Clades D, F, and Azokh) would be reminiscent from the original mitochondrial genome found in ancient M. blythii s.l. The South and Central Asian components of $M$. blythii remain so far unstudied with modern molecular methods of phylogeographic reconstructions, and thus their contributions in this scenario are unknown. 


\section{Genetic Diversity and Population Structure}

In accordance to their relatively recent (postglacial) movement of recolonization in Europe, populations of lesser mouse-eared bat are only very weakly structured over extensive areas. This is supported by the analysis of 8 microsatellite loci (i.e., hypervariable nuclear markers) genotyped in 84 samples of $M$. blythii collected throughout Europe and the Near East (Furman et al. 2014). Indeed, population structure inferred with a Bayesian assignation of genotypes suggested no significant population subdivision across this transect of over $1500 \mathrm{~km}$. This contrasts with the higher level of population structure measured at mtDNA markers, a pattern of cytonuclear discordance commonly found among other temperate bats (Castella et al. 2001; Burland and Worthington-Wilmer 2001). Such discordance among different classes of markers is explained by the fact that females (which transmit exclusively the mtDNA molecule to the next generation) exhibit strong philopatry, whereas males are much more vagile and may therefore transmit biparentally inherited markers (such as microsatellite loci) much further away from their natal range than mitochondrial markers. This male-mediated gene flow therefore may homogenize markers over large geographic areas, whereas mitochondrial ones move only locally.

\section{Hybridization with Related Species}

Since the advent of genetic methods to study wild populations, the former controversy about the species status of the two sibling taxa M. myotis and $M$. blythii has been settled. Indeed, multiple genetic evidences including comparisons throughout allozyme electrophoresis (Ruedi et al. 1990; Arlettaz et al. 1991) or multiple microsatellite loci (Castella et al. 2000; Furman et al. 2014; Berthier et al. 2006) demonstrate that these two taxa are well differentiated (see, for instance, the large Fst values in Table 4) and are evolving largely independently. However, more detailed molecular surveys conducted in several areas of sympatry in Switzerland, Italy, and France indicate that the two species are not reproductively fully isolated, as several genotyped individuals showed traces of introgression (Berthier et al. 2006; Afonso et al. 2017). Although no first-generation hybrid (F1) was evidenced in these regions, $10-15 \%$ of the surveyed bats were classified as late-generation hybrids or as backcrosses, suggesting the existence of rare but ongoing hybridization. These nuclear-based DNA studies also showed that most admixed bats were issued from asymmetric introgression of M. myotis alleles into $M$. blythii genotypes (Fig. 4). In the French Alps, all individuals showing traces of hybrid genomes were females (Afonso et al. 2017) further indicating that selection against

Table 4 Genetic diversity within Myotis blythii s.l. $(\mathrm{n}=84$ individuals analyzed) and $M$. myotis $(\mathrm{n}=113$ individuals) based on the genotype of 8 nuclear microsatellite loci. The fixation index $(F s t)$ measured between the two species at each locus and overall is also indicated. Beyond an Fst value of about 0.15 , this index suggests that there is practically no gene flow between the two assayed populations or species. Abbreviations: $A$ number of alleles; Ho observed heterozygosity; $H e$ expected heterozygosity. (Data from Furman et al. (2014))

\begin{tabular}{l|l|l|l|l|l|l|l|l}
\hline & \multicolumn{9}{l}{ M. blythii S.l. } & \multicolumn{3}{l}{ M. myotis } & \\
\hline Locus & A & Ho & He & A & Ho & He & & Fst \\
\hline C113 & 3 & 0.46 & 0.47 & 2 & 0.01 & 0.01 & 0.72 \\
\hline A2-Mluc & 13 & 0.83 & 0.84 & 9 & 0.62 & 0.70 & 0.21 \\
\hline G2-Mluc & 17 & 0.77 & 0.91 & 15 & 0.81 & 0.82 & 0.04 \\
\hline G6-Mluc & 11 & 0.77 & 0.85 & 7 & 0.43 & 0.65 & 0.13 \\
\hline G25 & 6 & 0.17 & 0.16 & 9 & 0.73 & 0.79 & 0.38 \\
\hline H23-Mluc & 17 & 0.80 & 0.89 & 14 & 0.84 & 0.87 & 0.02 \\
\hline A24-Mluc & 19 & 0.87 & 0.93 & 14 & 0.50 & 0.64 & & 0.21 \\
\hline D15-Mluc & 16 & 0.88 & 0.85 & 18 & 0.80 & 0.86 & & 0.06 \\
\hline & & & & & & & 0 Overall & 0.21 \\
\hline
\end{tabular}


Fig. 4 Hybrid index showing the probability $(\mathrm{Q}$ value) of an individual genotype to belong to the M. myotis parental form. In this index, a $\mathrm{Q}$ value of 0 means a pure (parental) $M$. blythii genotype, while a Q value of 1 indicates a pure $M$. myotis genotype. Q values comprised between 0.3 and 0.7 likely represent individuals with admixed (hybridized) genotypes. This index was calculated for 160 large Myotis bats sampled in Switzerland and Italy and genotyped at 5 hypervariable microsatellite loci. (Data redrawn from Berthier et al. (2006))

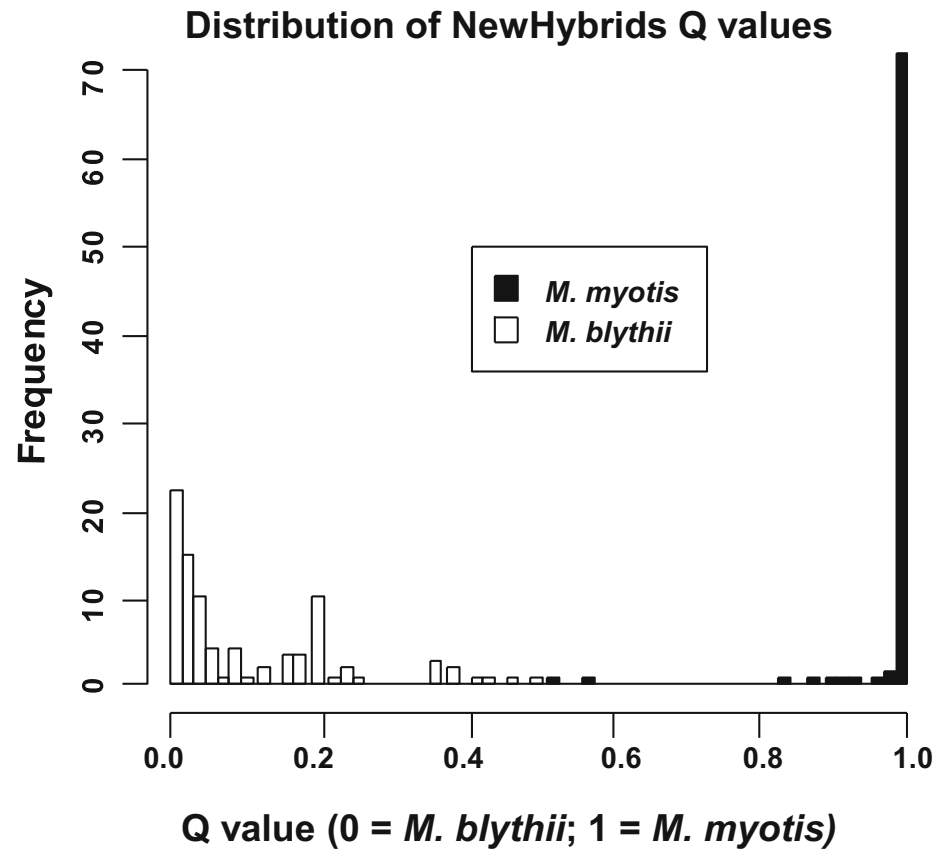

male hybrids might occur in this system. However, at larger geographic scales, Furman et al. (2014) found that the single probable F1 hybrid (out of 197 bats analyzed) was an adult male, implying that first-generation hybrid males are viable if not fertile. The existence of porous barriers between those two species in Europe, the strong asymmetric gene flow, and their contrasting demographic history led several authors to propose a model of recurrent replacement of the original mitogenome of $M$. blythii by that of M. myotis (Berthier et al. 2006; Petit and Excoffier 2009). This scenario also fits well with the multiple evidences of cytonuclear discordance observed in phylogenetic reconstructions (e.g., Furman et al. 2014; Castella et al. 2000).

\section{Life History}

The lesser mouse-eared bat follows the general life cycle of most temperate bats, with narrowly defined periods of reproduction, mating, and hibernation. Sex segregation in roosts is also prevalent during most of spring and summer. Although females may be sexually mature as early as at
3 months of age (Caël 2018), they usually start breeding during their second year of existence (Arlettaz et al. 2017). Females produce a single pup per year. Parturitions take place in maternity colonies that contain almost exclusively females, while adult males roost separately in the periphery or further away from these colonies. Most parturitions generally occur in June, but depending on the geographic location, this may happen in late May in the south or in June or even early July at higher latitudes (Uhrin et al. 2008; Dietz and Kiefer 2015). Furthermore, Arlettaz et al. (2001a) demonstrated that in Switzerland, this parturition date may also depend on food availability. Indeed, these researchers showed that $M$. blythii may postpone parturition date by several weeks, from mid-June to early July, depending on the availability earlier during the spring of a temporally abundant prey, the cockchafer (Melolontha melolontha). Such a food-dependent parturition date was not observed in M. myotis, which explains why the latter often gives birth to their babies 1 or 2 weeks earlier than sympatric $M$. blythii.

The newborns weight about $6 \mathrm{~g}$ and are weaned after 4-10 weeks but are able to fly 
already after 1 month (Sharifi 2004; Sharifi and Akmali 2006). The survival rate of juveniles in the nursery colonies is highly dependent of weather conditions, as colder and rainier summers can be particularly harmful to juveniles. The maternity colonies start to disperse by August, when the adult females become receptive for copulations.

As in other temperate bats (Senior et al. 2005), late summer or early autumn is the time when mating occurs, generally in different roosts than the nursery colonies. By the end of this breeding period, the precise date being dependent on local climatic conditions, lesser mouse-eared bats will seek caves or other underground habitats that are suitable for hibernation. Such caves are usually more humid, have lower ambient temperatures, and are located higher in altitude than those occupied by the nursery colonies (Uhrin et al. 2008). These bats may form large hibernating clusters or may roost singly in crevices or other small interstices. Hibernation will last until the first warmer days of spring, usually in late March or April.

\section{Lifespan}

Like in many other bats, $M$. blythii has an unusually long life expectancy given its small size for a mammal, with mean life expectancy probably over 4-5 years (Caël 2018). Most mortality occurs during the first year of life (Topál and Ruedi 2001; Arlettaz et al. 2017). Ringing studies conducted in southern and central Europe suggest that the vast majority of controlled animals are of a minimum age comprised between 1 and 6 years; only 4\% were in the age class of $7-10$ years and $2 \%$ over 11 years (Topál and Ruedi 2001; de Paz et al. 1986). The maximum lifespan recorded in $M$. blythii comes from two independent ringing studies: a male ringed presumably as a juvenile in a church attic in Valais (Switzerland) and controlled again in the same place 33 years later (Arlettaz et al. 2002); another individual was banded in the Szoplaki Ördöglyuk cave in northern Hungary in March 1952 and found 33 years and 8 months later in the Michňová cave in central Slovakia (Gaisler et al. 2003).
Known natural enemies preying more or less regularly on lesser mouse-eared bats include large owls (Bubo bubo, Strix aluco, and Tyto alba) and few crepuscular raptors like Falco species (for reviews, see Benda et al. 2012; Topál and Ruedi 2001). Small carnivores such as stone martens (Martes foina) and domestic cats (Felis catus) also predate regularly on mouse-eared bats (Gebhard 1997), but no specific cases have been reported for the lesser mouse-eared bat. When these enemies enter into nursery roosts or establish themselves in the same attic, the whole colony is strongly disturbed and may abandon the roost (Caël 2018).

\section{Habitat and Diet}

\section{Habitat}

In the Mediterranean region, lesser mouse-eared bats are gregarious and mostly troglophilous species which seek natural caves, mines, and other artificial underground shelters to establish their colonies or to find adequate hibernating sites. Isolated individuals, often males, may also roost in fissures in ruined buildings or under stone bridges (for a description of varied shelters, see, e.g., Benda et al. 2012). In more northern regions, $M$. blythii are anthropophilous and mainly occupy artificial roosts located in the attics of large houses or churches, where temperature is particularly elevated during the day (Uhrin et al. 2008). Such artificial, thermally favorable roosts are used by females to establish their nursery colonies, while alternative, cooler roosts are used by males or by nonreproductive individuals.

Lesser mouse-eared bats are typical inhabitants of open habitats, avoiding the more densely forested areas. Preferred foraging habitats include natural grasslands or steppe habitats, sparsely vegetated karstic landscapes, or open Mediterranean matorral scrublands. In more northerly regions such as in the Alpine Range, they also use agricultural landscapes and exploit in particular extensive meadows and pastures (Arlettaz 1999, 1996), as well as traditionally cultivated wetlands with dense grass cover (Güttinger et al. 
1998). All these habitats are rich in large ground arthropods like orthopterans (grasshoppers and crickets) and coleopterans, which are the preferred preys of M. blythii (Arlettaz 1996). These bats are known to hunt in such particularly cluttered habitats (Arlettaz et al. 2001b) and rely on passive listening of prey-generated sounds (Russo et al. 2007). Arlettaz and collaborators also established that the ecological niche segregation between the two sibling mouse-eared bat species is governed by the density of ground vegetation, with $M$. myotis favoring less-cluttered habitats as hunting grounds (Arlettaz 1999). However, in arid landscapes such as those found in Iran or Kyrgyzstan, where greater mouse-eared bats are absent, $M$. blythii may also hunt locusts and ground-dwelling coleopterans over almost bare grounds (Benda et al. 2012; Arlettaz et al. 1995; Benda et al. 2011), indicating that the preferred habitats of this species may vary considerably with geography.

\section{Spatial Movements}

Lesser mouse-eared bats are potent flyers able to commute at moderate speed, $30-40 \mathrm{~km} / \mathrm{h}$ (up to $55 \mathrm{~km} / \mathrm{h}$; see Caël 2018), and over large distances to find suitable hunting habitats (Arlettaz 1996). They leave day roosts about $30 \mathrm{~min}$ after sunset and hunt during most of the night, returning to their colonies about an hour before sunrise (Barataud 1992). Nursing females presumably return once during the night to their roost for suckling their baby, but this behavior was not observed in details (Arlettaz 1995). These mouse-eared bats can exploit foraging grounds situated up to $25 \mathrm{~km}$ away from the maternity roost, although hunting territories are usually established within 4-6 km of the colonies (Arlettaz 1999). In general, both males and females show pronounced site fidelity, whether in their summer and winter roosts (Gaisler et al. 2003; Uhrin et al. 2008; de Paz et al. 1986). One extreme case reported the presence of an individual roosting in the same wintering cave up to 22 years and 7 months after its initial capture (Uhrin et al. 2008).

Most of the maternity colonies are installed in the lowlands, usually below $800 \mathrm{~m}$ altitude, while wintering roosts may be located up to ca. $2000 \mathrm{~m}$ in the Alps (reviewed in Topál and Ruedi 2001) or even $2100 \mathrm{~m}$ in the Sierra Nevada in southern Spain (Nogeras and Garrido 2007). In Slovakia Uhrin et al. (2008) recorded 81\% summer roosts below $400 \mathrm{~m}$, while $91 \%$ hibernacula were located in the altitude range of $200-1000 \mathrm{~m}$.

$M$. blythii is considered as a largely sedentary species and usually limits seasonal movements to few tens of or a little over $150 \mathrm{~km}$ between summer and winter roosts (reviewed in Hutterer et al. 2005). The longest distance recorded for this species is that of a female ringed in May 1978 in a maternity colony in Tarifa (southern Spain) and controlled 10 months later in a cave in Ciempozuelos (near Madrid), some $488 \mathrm{~km}$ straight distance to the north. Such long-distance dispersals suggest that lesser mouse-eared bats are able to undertake longer journeys at least occasionally.

\section{Diet}

The lesser mouse-eared bat feeds on relatively large arthropods, with a marked preference for orthopterans (Gryllidae, Tettigoniidae, and Gryllotalpidae) and ground coleopterans like Scarabaeidae and Carabidae (Benda et al. 2011, 2012; Arlettaz 1996). However, when this food supply is scarce or only available as small larvae (e.g., during the spring), M. blythii may forage on other temporally abundant species such as cockchafers (Arlettaz 1996), suggesting that its hunting strategy is very flexible. Given the large geographic range inhabited by this species, its menu is also very variable and may include lepidopteran larvae, Tipulidae, hymenopterans or spiders in significant numbers, indicating that $M$. blythii is an opportunistic feeder (Arlettaz and Perrin 1995).

\section{Behavior}

\section{Foraging Behavior}

Lesser mouse-eared bat is a relatively large bat feeding mainly by gleaning its preys on the ground. Arlettaz (1996) summarized its hunting strategy as follows: During the search flight, this 
mouse-eared bat would fly slowly and close $(<1 \mathrm{~m})$ to the ground over grassy areas; if a prey is detected, it will then hover briefly over it and eventually will drop on it with outstretched wings; the prey is then seized with the mouth, and the bat takes off, consuming the captured arthropod on the wing during a widely circling flight that lasts less than a minute. Larger preys may also be consumed while perched under a branch. Each individual will be visiting one to several small foraging patches (2-14 ha each) during a single night. Other radio-tracking data reported by Caël (2018) suggest that members of a single colony may exploit a global area of several hundred hectares to over 10,000 ha, depending on which method is used to calculate the surface of hunting habitats.

In spring, when large concentration of cockchafers emerge locally, Arlettaz (1996) observed that lesser mouse-eared bats were taking this temporally abundant prey in the air by aerial-hawking, not by gleaning. This again is a clear sign that this bat is rather opportunistic and may adapt its hunting strategy and menu according to the local food offer.

\section{Resource Competition}

The competition over the trophic niche and habitat selection between the two sibling species $M$. blythii and M. myotis has been investigated by Arlettaz and co-authors (Arlettaz 1996; Arlettaz et al. 1997a) by examining a range of fecal samples collected during the active season and by radio-tracking experiments. They showed that the two species may coexist in strict sympatry owing to their general preferences for markedly distinct hunting habitats: the greater mouse-eared bat feeds mainly on ground beetles hunted in forests, while the lesser mouse-eared bats hunt preferentially ground arthropods in grasslands. When both species exploit temporally the same trophic resource (e.g., cockchafers in spring) or occasionally hunt over the same feeding patch during periods of high food abundance, they don't show agonistic behavior (Arlettaz 1995). These authors thus concluded that habitat selection rather than active interspecific competition or exclusion was the underlying mechanism responsible for their niche partitioning (Arlettaz et al. 1997a).

\section{Social Organization}

During the summer period, these highly gregarious bats tend to live in sex-segregated colonies, as is found in most other temperate bats (Senior et al. 2005). Females and their baby occupy the maternity colonies, while males roost singly in places away from these colonies. Nothing is known about the interactions between mother-pup pairs away from the nursery roosts, nor how juvenile learn how to hunt or how they establish their own territories. The behavior and social organization adopted during the mating season are described in more details in the section below, but it is only during this time and while occupying winter roost that these bats form mixed-gender aggregations.

\section{Home Range}

Radio-tracked females in the upper Rhône Valley in Switzerland (Arlettaz 1999) were hunting insects in foraging areas located about $4 \mathrm{~km}$ (up to $9 \mathrm{~km}$ ) away from their nursery colonies and were recorded in feeding grounds at an altitude of up to $2000 \mathrm{~m}$ a.s.l., whereas the roosts were found at between 470 and $675 \mathrm{~m}$ altitude. These females exploited a hunting territory of $38.1 \pm 11$ ha, mainly centered on south-facing slopes of the valley, where steppe vegetation and abundant ground arthropods were thriving. No comparable data have been gathered outside the maternity period nor in geographic settings outside the Alps. It is thus difficult to estimate how this pattern of habitat use applies to males, to other regions, or to other seasons during the year.

\section{Echolocation}

The echolocation calls of $M$. blythii are strongly frequency modulated (FM) signals starting at about $40-100 \mathrm{kHz}$ and, depending on the clutter 
level of the habitat, sweeping down to an end frequency of $26-36 \mathrm{kHz}$ (Russo and Jones 2002). Duration of each pulse is also highly dependent on the habitat and behavior of the bat (whether commuting in the open or hunting close to the vegetation) and varies between 2 and $7 \mathrm{~ms}$ (mean $4.3 \pm 1.23 \mathrm{~ms}$ ). Echolocation calls are emitted at intervals of 40-171 ms (mean $94.3 \pm 31.36 \mathrm{~ms}$ ). These frequency-modulated calls are very similar and generally indistinguishable from those emitted by free-flying greater mouse-eared bats (Barataud 2014; Skiba 2003). However, under controlled and standardized conditions, Russo and Jones (2002) showed that ultrasounds from both species recorded after being hand released in an open habitat differed statistically, M. blythii emitting slightly higher-pitched calls (mean frequency of maximum energy at $41.4 \pm 4.37 \mathrm{kHz}$ versus $39.1 \pm 5.22 \mathrm{kHz}$ in $M$. myotis).

\section{Reproductive Behavior}

In late summer, the nursery colonies start to decrease in numbers, as the adult females move to seek for other shelters, in particular where males have established small territories. The mating system and social organization of lesser mouse-eared bats during this mating period have been investigated in Greece (Hammer 1992), Austria (Spitzenberger 1988), the Czech Republic, and Bulgaria (Horácek and Gaisler 1985-86), and the general outlines emerging from these studies probably apply to other parts of their European distribution as well. Throughout the year, adult males stay in the periphery or further away from the large nursery colonies, but in late summer, they occupy small (about $1 \mathrm{~m}^{2}$ ), individual perching territories in the ceiling of caves or interstice of attics of buildings and other man-made structures. These day roosts are apparently occupied by a single male, which rubs the hanging place with the oily and odoriferous sebum secreted by the facial glands. During the mating time, which usually peaks in August and September, many such male territories are maintained in the same cave system or in artificial undergrounds, often near the entrance. The resident male will apparently defend its favorite hanging place against other male intruders but will also attract females by various displays, especially when bats return to the roost at dawn. Successful males are usually found hanging tightly to 1-4 (up to 6) females. They typically wrap these females with their wings and try to maintain them actively together in a dorsoventral position (see illustration in Benda et al. 2010). These interactions may be aggressive, the males biting or grasping the females trying to escape. Copulations occur in these small harems, but it is unknown whether these relationships are maintained outside those day roosts, nor whether the females will copulate with one or several mates before being fecundated. This polygynous, lek-like behavior characterizing the mating system of M. blythii (Horácek and Gaisler 1985-86) is therefore quite distinct from the mating behavior of many other temperate bat species visiting swarming sites during the breeding period (Piksa et al. 2011; van Schaik et al. 2015).

\section{Parasites and Diseases}

Lanza (1999) compiled the records of both endoand ectoparasites infesting $M$. b. oxygnathus from Italy. Among the endoparasites, he listed several unicellulars (including the blood parasite Trypanosoma dionisii), four species of cestodes (including Vampirolepis acuta), over 20 species of trematodes (including several species of Plagiorchis spp.), over 25 species of nematodes (including several Capillaria spp.), and many spiny-headed worms (Acanthocephala). Lanza also listed ectoparasites such as over 50 species of mites (including Macronyssus spp., Ixodes spp., and Spinturnix spp. to name the most common genera), bat flies (Nycteribia spp., Penicillidia spp.), fleas (such as Ischnopsyllus spp. or Pulex irritans), bugs (Cimex sp.), and an unknown dermestid. Insular populations of lesser mouse-eared bats have also been investigated by Sevcik et al. (2013) in Crete and Cyprus, but only two ectoparasite species were evidenced, namely, Nycteribia latreillii and Penicillidia dufourii. 
In the Middle East, Benda et al. (2012) report a number of ectoparasites on $M$. b. omari, including the bat flea (Ischnopsyllus dolosus), several bat flies (Nycteribia latreillii, N. vexata, N. schmidlii, Rhinolophopsylla unipectinata, and Penicillidia dufourii), and mites (Spinturnix myoti, Alabidocarpus calcaratus, and Nycteridocoptes poppei). A compilation of older mentions of ectoparasites of M. blythii s.l. can be found in (Topál and Ruedi 2001).

Although many of those parasites are known to be widespread and in general are not particularly host-specific (Bruyndonckx et al. 2009), Christe and colleagues (Christe et al. 2003, 2007) showed that the flight-membrane specialized mite Spinturnix myoti was affecting significantly less severely M. blythii than M. myotis where those two sibling species coexist in mixed-species colonies. These researchers also showed that bats in nutritionally good conditions, newborns, and especially gravid females were more susceptible to be infested by these blood-sucking mites, suggesting that such parasites prefer not only vulnerable but also well-fed hosts. The prevalence of these mites on wing membranes of juvenile lesser mouse-eared bats was close to $100 \%$.

Whereas positive serologic results of rabies virus antibodies have been evidenced in M. myotis from Spain (Serra-Cobo et al. 2002), similar surveys failed to find the presence of this virus in $M$. blythii in Europe (see review in Schatz et al. 2013). A related strain of the rabies virus in that species, however, has been detected in Central Asia (Kuzmin et al. 2003). Coronavirus have also been detected in Iberian lesser mouse-eared bat but in low prevalence ( 1 in 11 bats tested; Falcón et al. 2011).

\section{Population Ecology}

Lesser mouse-eared bats are highly gregarious species that coexist with several other troglophilous species in their roosts. Indeed most maternity roosts of $M$. blythii found across Europe are mixed colonies with M. myotis (Baratti et al. 1997; Uhrin et al. 2008; Spitzenberger 1988; Arlettaz 1995; Nogeras and Garrido 2007).
Exceptions include few Mediterranean islands like Crete or Cyprus, which only support monospecific populations of lesser mouse-eared bats (Georgiakakis et al. 2012; Benda et al. 2018), but others like Sicily (Toschi and Lanza 1959) or Lesvos (Hanak et al. 2001) host both species breeding in sympatry. In addition to hosting $M$. myotis, summer colonies of M. blythii may also be intermingled with several other bat species, including M. capaccinii, M. emarginatus, Miniopterus schreibersii, Rhinolophus euryale, or $R$. mehelyi (Caël 2018). In winter M. blythii is also found to roost together in mixed clusters with several of these troglophilous bats (reviewed in Topál and Ruedi 2001), suggesting that advantages of multispecies assemblages such as communal thermoregulation or lowered predation risks may offset the potential costs such as elevated parasite transmission induced by this gregarious behavior (Kerth 2008).

\section{Conservation Status}

Globally, the lesser mouse-eared bat is listed by IUCN (2016) as of least concern because it is still common in most of its Asiatic and East European range. However, it is rare or declining in many Western European countries and thus classified locally as near threatened (e.g., in France; Caël 2018), vulnerable (e.g., in Iberia, Cabral et al. 2005; Nogeras and Garrido 2007), or critically endangered (e.g., in Switzerland or Austria, Bohnenstengel et al. 2014; Spitzenberger 2001).

One of the main threats in Europe is the destruction or changes in its favorite hunting habitats (see chapter Habitat). Indeed, although the diet of lesser mouse-eared bat is rather eclectic, it largely depends on large, grass-dwelling species such as bush crickets or on seasonally abundant cockchafers, both of which tend to disappear with the intensification of agricultural practices (Marini et al. 2008; Dietz and Kiefer 2015). In particular large extensive steppes found in climatically favorable places are being converted to vineyards or intensive grasslands (Arlettaz 1995). Conversely, other threats to its main feeding habitats also include the abandonment of extensive 
pastureland and a concomitant development of woody vegetation, which provide less favorable conditions as hunting grounds for M. blythii (see chapter Foraging Behavior).

But perhaps the highest threat throughout the entire range of $M$. blythii is the increasing anthropogenic disturbance to roosts in caves and buildings. These troglophilous bats are easily disturbed by the repetitive intrusion of humans such as caving tourism, which induce large energetic costs to hibernating bats or may lead to the abandonment of entire breeding colonies. This phenomenon has been well documented in Spain (Juste and Paunović 2016), where up to $90 \%$ of the known roosts in Andalusia suffered from major human disturbance (Nogeras and Garrido 2007). Likewise, a nursery colony installed in a cave in Romania decrease by $95 \%$ due to increasing speleological activities. Roosts located in attics or steeples of churches may disappear following renovation or closure of accesses to avoid the intrusion of birds.

\section{Management}

Bats in general are all protected by national and international laws as most European countries agreed to protect bat populations under the UNEP/EUROBATS agreement (Hutson et al. 2015) and the BONN convention on migratory species. However, critical conservation actions to protect more specifically the lesser mouseeared bat should include a combination of management of hunting habitats and of roost protection. Controlling in particular the development of speleological activities near roosts, both for touristic and for caving enthusiasts, is critical to minimize disturbance for these sensitive troglophilous bats (Juste and Paunović 2016). The maintenance of pastures and open grasslands, including throughout extensive grazing, is also recommended to avoid the development of encroaching woody vegetation (Kyheröinen et al. 2019).

\section{Future Challenges for Research and Management}

The current difficulties of differentiating $M$. blythii from its sibling species M. myotis are a major problem hindering the monitoring of population trends in lesser mouse-eared bats. As $M$. blythii is clearly more at risk due to widespread declines of populations in most European countries, when compared to the great mouse-eared bat, this taxonomic challenge should be urgently solved. The taxonomic status of South Asian populations of $M$. blythii s.l., especially across the transition zones between omari and blythii, should also be investigated in more details, as the outcome of the biological interaction between these two ecomorphs might challenge the current taxonomic status of the European lesser mouseeared bats.

The closure of underground habitats with iron gates and horizontal bar spacing is often a solution to reduce human encroachment. However, it is unclear whether such designs are appropriate for all species, including $M$. blythii, and during the entire life cycle of those bats (Tobin and Chambers 2017). More research is needed in this field as well.

Acknowledgments I would like to thank Cyril Schönbächler for his nice photo of lesser mouse-eared bat and three anonymous reviewers for useful suggestions concerning the conservation of this species in Western Europe.

\section{References}

Afonso E, Goydadin AC, Giraudoux P, Farny G (2017) Investigating hybridization between the two sibling bat species Myotis myotis and M. blythii from guano in a natural mixed maternity colony. PLoS One 12(2): e0170534. https://doi.org/10.1371/journal.pone.0170534

Altringham JD (2011) Bats. From evolution to conservation. Oxford University Press, Oxford

Arlettaz R (1995) Ecology of the sibling mouse-eared bats (Myotis myotis and M. bythii): zoogeography, niche, competition, and foraging. Institut de Zoologie et d'Ecologie Animale, University of Lausanne/Horus Publishers, Martigny

Arlettaz R (1996) Feeding behaviour and foraging strategy of free-living mouse-eared bats, Myotis myotis and 
Myotis blythii. Anim Behav 51:1-11. https://doi.org/ 10.1006/anbe.1996.0001

Arlettaz R (1999) Habitat selection as a major resource partitioning mechanism between the two sympatric sibling bat species Myotis myotis and Myotis blythii. J Anim Ecol 68(3):460-471

Arlettaz R, Perrin N (1995) The trophic niches of sympatric sibling Myotis myotis and M. blythii: do mouse-eared bats select prey? Symp Zool Soc Lond 67:361-376

Arlettaz R, Ruedi M, Hausser J (1991) Field morphological identification of Myotis myotis and Myotis blythii (Chiroptera, Vespertilionidae): a multivariate approach. Myotis 29:7-16

Arlettaz R, Dändliker G, Kasybekov E, Pillet JM, Rybin S, Zima J (1995) Feeding habits of the long-eared desert bat, Otonycteris hemprichii (Chiroptera, Vespertilionidae). J Mammal 76(3):873-876

Arlettaz R, Perrin N, Hausser J (1997a) Trophic resource partitioning and competition between the two sibling bat species Myotis myotis and Myotis blythii. J Anim Ecol 66(6):897-911

Arlettaz R, Ruedi M, Ibañez C, Palmeirim J, Hausser J (1997b) A new perspective on the zoogeography of the sibling mouse-eared bat species Myotis myotis and $M$. blythii: morphological, genetical and ecological evidence. J Zool 242:45-62

Arlettaz R, Christe P, Lugon A, Perrin N, Vogel P (2001a) Food availability dictates the timing of parturition in insectivorous mouse-eared bats. Oikos 95(1):105-111

Arlettaz R, Jones G, Racey PA (2001b) Effect of acoustic clutter on prey detection by bats. Nature 414 (6865):742-745

Arlettaz R, Christe P, Desfayes M (2002) 33 years, a new longevity record for a European bat. Mammalia 66 (3):441-442

Arlettaz R, Christe P, Schaub M (2017) Food availability as a major driver in the evolution of life-history strategies of sibling species. Ecol Evol 7(12):4163-4172. https:// doi.org/10.1002/ece3.2909

Arslan A, Zima J (2014) Karyotypes of the mammals of Turkey and neighbouring regions: a review. Folia Zool 63(1):1-63

Așan N, Albayrak İ, Yorulmaz T (2010) Noteworthy records of Myotis myotis and Myotis blythii in Turkey (Chiroptera: Vespertilionidae). Lynx, ns 41:145-150

Așan N, Albayrak I, Yorulmaz T, Inci S (2011) G-banding karyotypes of Myotis myotis (Borkhausen, 1797) and Myotis blythii (Tomes, 1857) (Mammalia: Chiroptera) in Turkey. Turk J Zool 35(4):599-602

Bachanek J (2008) The northern distribution limits of the lesser mouse-eared bat Myotis oxygnathus (Chiroptera: Vespertilionidae) in Central Europe. Acta Zool Cracov 51(1-2):59-64

Bachanek J, Postawa T (2010) Morphological evidence for hybridization in the sister species Myotis myotis and Myotis oxygnathus (Chiroptera: Vespertilionidae) in the Carpathian Basin. Acta Chiropterol 12(2):439-448. https://doi.org/10.3161/150811010x538007
Ballard JWO, Whitlock MC (2004) The incomplete natural history of mitochondria. Mol Ecol 13:729-744

Barataud M (1992) L'activité crépusculaire et nocturne de 18 espèces de chiroptères, révélée par marquage luminescent et suivi acoustique. Le Rhinolophe 9:23-57

Barataud M (2014) Écologie acoustique des Chiroptères d'Europe: Identification des espèces, étude de leurs habitats et comportements de chasse. Inventaires et Biodiversité, 2e edn. Biotopes Editions

Baratti N, Debernardi P, Patriarca E, Sindaco R (1997) Breeding colonies of Myotis myotis and Myotis blythii in Piedmont and Aosta Valley (NW Italy): characterization and conservation. Hystrix 9:61-64

Benda P, Gaisler J (2015) Bats (Mammalia: Chiroptera) of the Eastern Mediterranean and Middle East. Part 12. Bat fauna of Afghanistan: revision of distribution and taxonomy*. Acta Soc Zool Bohem 79:267-458

Benda P, Horácek I (1995) Biometrics of Myotis myotis and Myotis blythii. Myotis 32-33:45-55

Benda P, Horácek I (1998) Bats (Mammalia: Chiroptera) of the Eastern Mediterranean. Part 1. Review of distribution and taxonomy of bats in Turkey. Acta Soc Zool Bohem 62:255-313

Benda P, Andreas M, Kock D, Lucan R, Munclinger P, Nova P, Obuch J, Ochman K, Reiter A, Uhrin M, Weinfurtova D (2006) Bats (Mammalia: Chiroptera) of the Eastern Mediterranean. Part 4. Bat fauna of Syria: distribution, systematics, ecology. Acta Soc Zool Bohem 70:1-329

Benda P, Hanak V, Horácek I, Hulva P, Lucan R, Ruedi M (2007) Bats (Mammalia: Chiroptera) of the Eastern Mediterranean. Part 5. Bat fauna of Cyprus: review of records with confirmation of six species new for the island and description of a new subspecies. Acta Soc Zool Bohem 71:71-130

Benda P, Georgiakakis P, Dietz C, Hanak V, Galanaki K, Markantonatou V, Chudarkova A, Hulva P, Horácek I (2009) Bats (Mammalia: Chiroptera) of the Eastern Mediterranean. Part 7. The bat fauna of Crete, Greece. Acta Soc Zool Bohem 72:105-190

Benda P, Lucan R, Obuch J, Reiter A, Andreas M, Backor P, Bohnenstengel T, Eid EK, Sevcik M, Vallo P (2010) Bats (Mammalia: Chiroptera) of the Eastern Mediterranean and Middle East. Part 8. Bats of Jordan: fauna, ecology, echolocation, ectoparasites. Acta Soc Zool Bohem 74(3-4):185-353

Benda P, Hanák V, Červený J (2011) Bats (Mammalia: Chiroptera) of the Eastern Mediterranean and Middle East. Part 9. Bats from Transcaucasia and West Turkestan in collection of the National Museum, Prague. Acta Soc Zool Bohem 75:159-222

Benda P, Faizolâhi K, Andreas M, Obuch J, Reiter A, Ševcik M, Uhrin M, Vallo P, Ashrafi S (2012) Bats (Mammalia: Chiroptera) of the Eastern Mediterranean and Middle East. Part 10. Bat fauna of Iran. Acta Soc Zool Bohem 76:163-582

Benda P, Satterfield L, Gücel S, Horáček I, Lučan R, Charalambidou I, Uhrin M (2018) Distribution of bats in Northern Cyprus (Chiroptera). Lynx 49:91-138 
Berthier P, Excoffier L, Ruedi M (2006) Recurrent replacement of mtDNA and cryptic hybridization between two sibling bat species Myotis myotis and Myotis blythii. Proc R Soc Lond [Biol] 273:3101-3109

Bihari Z (1998) Examination of the settlement of Myotis myotis in an abandoned mine. Myotis 36:225-228

Bogdanowicz W, Van Den Bussche RA, Gajewska M, Postawa T, Harutyunyan M (2009) Ancient and contemporary DNA sheds light on the history of mouseeared bats in Europe and the Caucasus. Acta Chiropterol 11(2):289-305. https://doi.org/10.3161/ 150811009x485530

Bohnenstengel T, Krättli H, Obrist MK, Bontadina F, Jaberg C, Ruedi M, Moeschler P (2014) Liste rouge Chauves-souris. Espèces menacées en Suisse, état 2011. L'environnement pratique $n^{\circ}$, vol 1412. Office fédéral de l'environnement, Berne; Centre Suisse de Cartographie de la Faune, Neuchâtel; Centres suisses de coordination pour l'étude et la protection des chauves-souris, Genève et Zurich; Institut fédéral de recherches sur la forêt, la neige et le paysage, Birmensdorf, Bern and Neuchâtel, Switzerland

Bruyndonckx N, Dubey S, Ruedi M, Christe P (2009) Molecular cophylogenetic relationships between European bats and their ectoparasitic mites (Acari, Spinturnicidae). Mol Phylogenet Evol 51:227-237

Burgin CJ, Colella JP, Kahn PL, Upham NS (2018) How many species of mammals are there? J Mammal 99 (1):1-14. https://doi.org/10.1093/jmammal/gyx147

Burland TM, Worthington-Wilmer J (2001) Seeing in the dark: molecular approaches to the study of bat populations. Biol Rev 76(3):389-409. https://doi.org/ 10.1017/S1464793101005747

Cabral MJ, Almeida J, Almeida PR, Dellinger T, Ferrand de Almeida N, Oliveira M, Palmeirim J, Queirós A, Rogado L, Santos-Reis M (eds) (2005) Livro vermelho dos vertebrados de Portugal. Instituto da Conservação da Natureza, Lisboa

Caël G (2018) Synthèse bibliographique: Le Petit murin, Myotis blythii (Tomes, 1857). CPEPESC FrancheComté, Besançon

Castella V, Ruedi M, Excoffier L, Ibáñez C, Arlettaz R, Hausser J (2000) Is the Gibraltar Strait a barrier to gene flow for the bat Myotis myotis (Chiroptera: Vespertilionidae)? Mol Ecol 9:1761-1772

Castella V, Ruedi M, Excoffier L (2001) Contrasted patterns of mitochondrial and nuclear structure among nursery colonies of the bat Myotis myotis. J Evol Biol 14:708-720

Christe P, Giorgi MS, Vogel P, Arlettaz R (2003) Differential species-specific ectoparasitic mite intensities in two intimately coexisting sibling bat species: resourcemediated host attractiveness or parasite specialization? J Anim Ecol 72(5):866-872

Christe P, Glaizot O, Evanno G, Bruyndonckx N, Devevey G, Yannic G, Patthey P, Maeder A, Vogel P, Arlettaz R (2007) Host sex and ectoparasites choice: preference for, and higher survival on female hosts. J Anim Ecol 76(4):703-710
Coraman E, Furman A, Karatas A, Bilgin R (2013) Phylogeographic analysis of Anatolian bats highlights the importance of the region for preserving the Chiropteran mitochondrial genetic diversity in the Western Palaearctic. Conserv Genet 14(6):1205-1216. https:// doi.org/10.1007/s10592-013-0509-4

Corbet GB (1978) The mammals of the Palaearctic Region: a taxonomic review. Cornell University Press, London

de Paz O, Fernandez R, Benzal J (1986) El anillamiento de quiropteros en el centro de la Peninsula Iberica durante el periodo 1977-1986. Bol Estacion Central Ecol 30:113-138

Dietz C, Kiefer A (2015) Les chauves-souris d'Europe. Connaître, déterminer, protéger. Delachaux et Niestlé, Paris

Dietz C, von Helversen O, Nill D (2007) Handbuch der Fledermäuse Europas und Nordwestafrikas. Biologie, Kennzeichen, Gefährdung. Kosmos Naturführer. Kormos Verlags GmbH \& Co KG, Stuttgart

Ellerman JR, Morrison-Scott TCS (1951) Checklist of Palaearctic and Indian mammals, 1758 to 1946, 1st edn. Tonbridge Printers, Tonbridge

Evin A, Baylac M, Ruedi M, Mucedda M, Pons JM (2008) Taxonomy, skull diversity and evolution in a species complex of Myotis (Chiroptera: Vespertilionidae): a geometric morphometric appraisal. Biol J Linn Soc 95:529-538

Falcón A, Vázquez-Morón S, Casas I, Aznar C, Ruiz G, Pozo F, Perez-Breña P, Juste J, Ibáñez C, Garin I, Aihartza J, Echevarría JE (2011) Detection of alpha and betacoronaviruses in multiple Iberian bat species. Arch Virol 156(10):1883. https://doi.org/10.1007/ s00705-011-1057-1

Felten H, Spitzenberger F, Storch G (1977) Zur Kleinsäugerfauna West-Anatoliens. Teil IIIa. Senckenberg Biol 58:1-44

Furman A, Coraman E, Nagy ZL, Postawa T, Bilgin R, Gajewska M, Bogdanowicz W (2013) Phylogeography of the large Myotis bats (Chiroptera: Vespertilionidae) in Europe, Asia Minor, and Transcaucasia. Biol J Linn Soc 108(1):189-209. https://doi.org/10.1111/j.10958312.2012.01994.x

Furman A, Çoraman E, Çelik YE, Postawa T, Bachanek J, Ruedi M (2014) Cytonuclear discordance and the species status of Myotis myotis and Myotis blythii (Chiroptera). Zool Scr 43(6):549-561. https://doi.org/ 10.1111/zsc. 12076

Gaisler J, Hanák V, Hanzal V, Jarský V (2003) Results of bat banding in the Czech and Slovak Republics, 19482000. Vespertilio 7:3-61

Galán J, Núñez-Lahuerta C, Sauqué V, Cuenca-Bescós G, López-García JM (2019) Cranial biometrics of the Iberian Myotis myotis/Myotis blythii complex: new data for studying the fossil record. J Mammal Evol 26:333344. https://doi.org/10.1007/s10914-018-9427-z

Galimberti A, Martinoli A, Russo D, Mucedda M, Casiraghi M (2010) Molecular identification of Italian Mouse-eared bats (genus Myotis). In: Tools for identifying biodiversity: progress and problems. Proceedings 
of the international congress, Paris, September 20-22, 2010. EUT Edizioni Università di Trieste, Trieste

Gebhard J (1997) Fledermäuse. Birkäuser, Basel

Georgiakakis P, Kaidatzi S, Benda P (2012) Morphometrics of Myotis blythii from Crete: a taxonomic transition or an island effect. Vespertilio 16:139-147

Ghazali M (2009) Identification of Myotis blythii and $M$. myotis (Chiroptera, Vespertilionidae) from Eastern Europe based on the measurements of lower teeth. Vestnik zoologii 43(5):403-408

Güttinger R, Lustenberger J, Beck A, Weber U (1998) Traditionally cultivated wetland meadows as foraging habitats of the grass-gleaning lesser mouse-eared bat (Myotis blythii). Myotis 36:41-49

Hammer M (1992) Untersuchungen zum Paarungssystem des Kleinen Mausohrs (Myotis blythii) an individuell markierten Tieren eines Balzverbandes in Nordgriechenland. Unpublished master thesis, Julius Maximilians-Universität, Würzburg

Hanak V, Benda P, Ruedi M, Horácek I, Sofianidou TS (2001) Bats (Mammalia: Chiroptera) of the Eastern Mediterranean. Part 2. New records and review of distribution of bats in Greece. Acta Soc Zool Bohem 65:279-346

Harrison DL, Lewis RE (1961) The large mouse-eared bats of the Middle East, with description of a new subspecies. J Mammal 42(3):372-380

Horácek I, Gaisler J (1985-86) The mating system of Myotis blythii. Myotis 23-24:125-129

Hutson AM, Marnell F, Torv T (2015) A guide to the implementation of the Agreement on the Conservation of Populations of European Bats (EUROBATS). Version 1 edn. UNEP/EUROBATS Secretariat, Bonn

Hutterer R, Ivanova T, Meyer-Cords C, Rodrigues L (2005) Bat migrations in Europe. A review of banding data and literature, vol 28. Naturschutz und Biologische Vielfalt. Federal Agency for Nature Conservation, Bonn

Ibáñez C, García-Mudarra JL, Ruedi M, Stadelmann B, Juste J (2006) The Iberian contribution to cryptic diversity in European bats. Acta Chiropterol 8(2):277-297. https:// doi.org/10.3161/1733-5329(2006)8[277,TICTCD]2.0

Iliopoulou-Georgudaki J (1984) Intraspecific and interpopulation morphologic variation in the sharpeared bat, Myotis blythii (Tomes, 1857) (Chiroptera: Vespertilionidae), from Greece. Bonner zool Beitr 35:15-24

Johnson JS, Lacki MJ (2014) Effects of reproductive condition, roost microclimate, and weather patterns on summer torpor use by a vespertilionid bat. Ecol Evol 4(2):157-166. https://doi.org/10.1002/ece3.913

Juste J, Paunović M (2016) Myotis blythii. The IUCN Red List of Threatened Species 2016:e.T14124A22053297. https://doi.org/10.2305/IUCN.UK.2016-2.RLTS.T141 24A22053297.en

Karataş A, Yiğit N, Kankılıç T, Çolak E (2004) Contribution to the distribution and karyology of some vespertilionid bats (Mammalia: Chiroptera) from Turkey. Zool Middle East 31(1):5-12
Karataş A, Gharakheloo MM, Kankiliç T (2008) Karyotypes of two Iranian bat species, Myotis blythii and Miniopterus schreibersii (Chiroptera: Vespertilionidae, Miniopteridae). Turk J Zool 32(3):305-308

Kerth G (2008) Causes and consequences of sociality in bats. Bioscience 58(8):737-746

Koopman KF (1994) Chiroptera: systematics. In: Niethammer J, Schliemann H, Starck D (eds) Handbuch der Zoologie, vol 8. de Gruyter, Berlin, pp 100-109

Kordos L (1981) The evolution in the past ten thousand years of the vertebrate fauna of the Hungarian central mountain range [in Hungarian with English summary]. Állatt Közl 71:109-117

Kruskop SV, Borisenko AV, Ivanova NV, Lim BK, Eger JL (2012) Genetic diversity of northeastern Palaearctic bats as revealed by DNA barcodes. Acta Chiropterol 14(1):114. https://doi.org/10.3161/150811012x654222

Kuzmin IV, Orciari LA, Arai YT, Smith JS, Hanlon CA, Kameoka Y, Rupprecht CE (2003) Bat lyssaviruses (Aravan and Khujand) from Central Asia: phylogenetic relationships according to $\mathrm{N}, \mathrm{P}$ and $\mathrm{G}$ gene sequences. Virus Res 97(2):65-79

Kyheröinen E-M, Aulagnier S, Dekker J, Dubourg-Savage MJ, Ferrer B, Gazaryan S, Georgiakakis P, Hamidovic D, Harbusch C, Haysom K, Jahelkova H, Kervyn T, Koch M, Lundy M, Marnell F, Mitchell-Jones A, Pir J, Russo D, Schofield H, Syvertsen PO, Tsoar A (2019) Guidance on the conservation and management of critical feeding areas and commuting routes for bats, vol 9. Publication series. UNEP/EUROBATS Secretariat, Bonn

Lanza B (1999) I parassiti dei pipistrelli (Mammalia, Chiroptera) della fauna italiana, vol 30. Museo regionale di scienze naturali, Torino

Marini L, Fontana P, Scotton M, Klimek S (2008) Vascular plant and Orthoptera diversity in relation to grassland management and landscape composition in the European Alps. J Appl Ecol 45(1):361-370

Mayer F, von Helversen O (2001) Cryptic diversity in European bats. Proc R Soc Lond [Biol] 268:1825-1832. https://doi.org/10.1098/rspb.2001.1744

Mendelssohn H, Yom-Tov Y (1999) Mammalia of Israel: Fauna Palaestina. The Israel Academy of Sciences and Humanities, Jerusalem

Menu H, Sigé B (1971) Nyctalodontie et myotodontie, importants caractères de grades évolutifs chez les chiroptères entomophages. Comptes Rendus l'Acad Sci Paris 272:1735-1738

Miller GS (1897) XLVI. The nomenclature of some European bats. Ann Mag Nat Hist 20(118):379-385. https:// doi.org/10.1080/00222939708680647

Monticelli FS (1885) Descrizione di un nuovo Vespertilio Italiano. Ann Accad O Costa Aspir Nat 1:82

Morales AE, Ruedi M, Field K, Carstens BC (2019) Diversification rates have no effect on the convergent evolution of foraging strategies in the most speciose genus of bats, Myotis. Evolution 73:2263-2280. https://doi.org/ 10.1111/evo. 13849 
Nogeras J, Garrido JA (2007) Myotis blythii (Tomes, 1857). In: Palomo LJ, Gisbert J, Blanco JC (eds) Atlas y Libro Rojo de los mammiferos terrestres de España. Direccion General para la Biodiversidad SECEM-SECEMU, Madrid, pp 158-162

Petit RJ, Excoffier L (2009) Gene flow and species delimitation. Trends Ecol Evol 24(7):386-393

Piksa K (2006) First record of Myotis blythii in Poland (Chiroptera: Vespertilionidae). Lynx 37:197-200

Piksa K, Bogdanowicz W, Tereba A (2011) Swarming of bats at different elevations in the Carpathian Mountains. Acta Chiropterol 13(1):113-122. https://doi.org/ $10.3161 / 150811011 \times 578660$

Popov V, Ivanova T (1995) Morphoecological analysis and late quaternary history of a bat community in a karstic landscape of North Bulgaria. Myotis 32(33):21-31

Rainho A, Alves P, Amorim F, Marques JT (2013) Atlas dos morcegos de Portugal continental. Instituto da Conservação da Natureza e das Florestas, Lisboa

Ransome R (1990) The natural history of hibernating bats. C. Helm, London

Ruedi M, Mayer F (2001) Molecular systematics of bats of the genus Myotis (Vespertilionidae) suggests deterministic ecomorphological convergences. Mol Phylogenet Evol 21(3):436-448

Ruedi M, Arlettaz R, Maddalena T (1990) Distinction morphologique et biochimique de deux espèces jumelles de chauves-souris: Myotis myotis (Bork.) et Myotis blythii (Tomes) (Mammalia; Vespertilionidae). Mammalia 54:415-429

Ruedi M, Stadelmann B, Gager Y, Douzery EJP, Francis CM, Lin L-K, Guillén-Servent A, Cibois A (2013) Molecular phylogenetic reconstructions identify East Asia as the cradle for the evolution of the cosmopolitan genus Myotis (Mammalia, Chiroptera). Mol Phylogenet Evol 69(3):437-449. https://doi.org/ 10.1016/j.ympev.2013.08.011

Russo D, Jones G (2002) Identification of twenty-two bat species (Mammalia: Chiroptera) from Italy by analysis of time-expanded recordings of echolocation calls. J Zool 258(1):91-103. https://doi.org/10.1017/ S0952836902001231

Russo D, Jones G, Arlettaz R (2007) Echolocation and passive listening by foraging mouse-eared bats Myotis myotis and M. blythii. J Exp Biol 210:166-176

Salari L (2010) Lateglacial bats from the "M" layers of the Arene Candide Cave (Liguria, Italy). Riv Ital Paleontol S 116(1):119-138

Salari L, Kotsakis T, Petronio C (2013) Early Pleistocene Bats from Pirro Nord (Apulia, Southern Italy). Palaeontogr Abt A 298:55-72

Salari L, Agnelli P, Calcagnile L, Di Maita J, Grasso R, Quarta C, Santoro C, Spena MT (2019) The fossil bat assemblages from the Grotta dei Pipistrelli in Pantalica (southeastern Sicily, Italy): Chronological and palaeoecological implications. Comptes Rendus Palevol 18(4):417-441. https://doi.org/10.1016/j. crpv.2019.01.007
Schatz J, Fooks AR, McElhinney L, Horton D, Echevarria J, Vázquez-Moron S, Kooi EA, Rasmussen TB, Müller T, Freuling CM (2013) Bat rabies surveillance in Europe. Zoonoses Public Health 60(1):22-34

Senior P, Butlin RK, Altringham JD (2005) Sex segregation in temperate bats. Proc R Soc Lond [Biol] 272:2467-2473

Serra-Cobo J, Amengual B, Abellan C, Bourhy H (2002) European bat Lyssavirus infection in Spanish bat populations. Emerg Infect Dis 8(4):413-420

Sevcik M, Benda P, Lucan RK (2013) Diptera pupipara from bats of two large eastern Mediterranean islands, Crete and Cyprus. Turk J Zool 37(1):31-37

Sevilla P (1988) Estudio paleontologico de los quiropteros del Cuaternario español. Paleontol Evol 22:113-233

Sevilla P (1989) Quaternary fauna of bats in Spain: paleoecologic and biogeographic interest. In: Hanák V, Horácek I, Gaisler J (eds) European bat research 1987. Charles University Press, Praha, pp 349-355

Sevilla P (2016) Bats from Azokh Caves. In: FernándezJalvo Y, King T, Yepiskoposyan L, Andrews P (eds) Azokh Cave and the Transcaucasian Corridor. Springer International Publishing, Cham, pp 177-189. https:// doi.org/10.1007/978-3-319-24924-7_8

Sharifi M (2004) Postnatal growth in Myotis blythii (Chiroptera, Vespertilionidae). Mammalia 68(4):283289. https://doi.org/10.1515/mamm.2004.027

Sharifi M, Akmali V (2006) Postnatal growth in the Lesser Mouse-eared bat, Myotis blythii, in captivity. Zool Middle East 37(1):13-20

Simmons NB (2005) Order Chiroptera. In: Wilson DE, Reeder DM (eds) Mammal species of the World. A taxonomic and geographic reference, vol 1, 3nd edn. Johns Hopkins University Press, Washington, pp 312529

Skiba R (2003) Europäische Fledermäuse. Kennzeichen, Echoortung und Detektoranwendung, Bd. 648. Die Neue Brehm-Bücherei. Westrap Wissenschaften, Hohenwarsleben

Spitzenberger F (1988) Grosses und Kleines Mausohr, Myotis myotis Borkhausen, 1797, und Myotis blythi Tomes 1857 (Mammalia, Chiroptera) in Österreich. Mitt Abt Zool Landesmus Joann Graz 42:1-68

Spitzenberger F (1996) Distribution and subspecific variation of Myotis blythii and Myotis myotis in Turkey (Mamm., Vespertilionidae). Ann Nat Hist Mus Wien Ser B 98:9-23

Spitzenberger F (2001) Die Säugetierfauna Österreichs, vol 13. Bundesministerium für land-und Forstwirtschaft Umwelt and Wasserwirtschaft, Gratz

Strelkov P (1972) Myotis blythii (Tomes, 1857): distribution, geographical variability and differences from Myotis myotis (Borkhausen, 1797). Acta Theriol 17:355-380

Thomas O (1905) On a collection of mammals from Persia and Armenia presented to the British Museum by Col. A.C. Bailward. Proc Zool Soc Lond 2:519-527

Thomas O (1910) A collection of small mammals from China. Proc Zool Soc Lond 39:635-639 
Tobin A, Chambers CL (2017) Mixed effects of gating subterranean habitat on bats: a review. J Wildl Manag 81(7):1149-1160

Tomes RF (1857) Descriptions of four undescribed species of bats. Proc Zool Soc Lond 1857:50-54. https://doi. org/10.1111/j.1096-3642.1857.tb01197.x

Topál G (1971) The taxonomic distinction of Myotis dobsoni (Trouessart, 1879) and some statistical data to the subspecific examination of Myotis blythii (Tomes, 1857). Ann Hist Nat Mus Nat Hung 63:383-400

Topál G (1983) New and rare fossil mouse-eared bats from the Middle Pliocene of Hungary (Mammalia, Chiroptera). Fragm Min Palaeont 11:43-54

Topál G, Ruedi M (2001) Myotis blythii (Tomes, 1857) Kleines Mausohr. In: Krapp F (ed) Handbuch der Säugetiere Europas Bd 4/I (Fledertiere), vol 4/I. AULA-Verlag GmbH, Wiebelsheim, pp 209-255

Topál G, Tusnadi G (1963) Data for craniometric investigation of Myotis myotis Borkh. and Myotis oxygnathus Montic. in Hungary. Ann Hist Nat Mus Nat Hung 55:543-549
Toschi A, Lanza B (1959) Fauna d'Italia Mammalia: Generalità - Insectivora - Chiroptera. Edizione Calderini, Bologna

Uhrin M, Benda P, Obuch J, Danko Š (2008) Lesser mouse-eared bat (Myotis blythii) in Slovakia: distributional status with notes on its biology and ecology (Chiroptera: Vespertilionidae). Lynx 39(1):153-190

van Schaik J, Janssen R, Bosch T, Haarsma A-J, Dekker JJ, Kranstauber B (2015) Bats swarm where they hibernate: compositional similarity between autumn swarming and winter hibernation assemblages at five underground sites. PLoS One 10(7):e0130850

Volleth M, Heller KG (2012) Variations on a theme: karyotype comparison in Eurasian Myotis species and implications for phylogeny. Vespertilio 16:329-350

Zima I (1982) Chromosomal homology in the complements of bats of the family Vespertilionidae. II. Gband karyotypes of some Myotis, Eptesicus and Pipistrellus species. Folia Zool 31(1):31-36 